1

2 3 the Netherlands Antilles

4

4 152742, Russia Columbia, Canada

\title{
European Journal of Protistology
}

\section{Heterotrophic flagellates and centrohelid heliozoans from marine waters of Curacao,}

Kristina I. Prokina ${ }^{\text {a, b, * }}$, Patrick J. Keeling ${ }^{c}$, Denis V. Tikhonenkov ${ }^{a}$

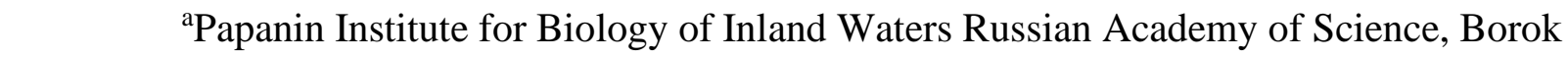

${ }^{\mathrm{b}}$ Laboratory of cellular and molecular protistology, Zoological Institute Russian Academy of Science, Saint Petersburg 199034, Russia

0 cDepartment of Botany, University of British Columbia, Vancouver, V6T 1Z4, British

Abstract. Recent progress in understanding the early evolution of eukaryotes was tied to morphological identification of flagellates and heliozoans in the natural samples, isolation of their cultures and genomic and ultrastructural investigations. These protists are the smallest and least studied microbial eukaryotes but play an important role in functioning of microbial food webs.

Using light and electron microscopy, we have studied the diversity of heterotrophic flagellates and centrohelid heliozoans from marine waters of Curacao (The Netherlands Antilles), and provide micrographs and morphological descriptions of observed species. Among 86 flagellates and 3 centrohelids encountered in this survey, five heterotrophic flagellates and one centrohelid heliozoan were not identified even to the genus. Some flagellate protists have a unique morphology, and may represent undescribed lineages of eukaryotes of high taxonomic rank. The vast majority (89\%) of identified flagellates are characterized by wide geographical distribution and had been reported previously from all hemispheres and various climatic regions. More than half of the species were previously observed not only from marine, but also from freshwater 
habitats. The parameters of the species accumulation curve indicate that our species list obtained

27 for the Curacao study sites is far from complete, and each new sample should yield new species.

Key words: protists, heterotrophic flagellates, centrohelids, morphology, electron

microscopy, Caribbean Sea

Abbreviations: SEM - scanning electron microscopy, TEM - transmission electron microscopy, LM - light microscopy, $\mathrm{PhC}$ - phase contrast, DIC - differential interference contrast

*Corresponding author

Email address: kristin892@mail.ru

\section{INTRODUCTION}

Heterotrophic flagellates and centrohelid heliozoans are the smallest and least studied

collective name for an extremely diverse "hodgepodge" of polyphyletic, colorless protists moving

or feeding with flagella at least in one stage of their life cycle (Patterson and Larsen 1991) - are

characterized by significantly variety of metabolism and ecology. At the same time centrohelid

heliozoans (Centroplasthelida Febvre-Chevalier et Febvre, 1984) is a monophyletic group of

predatory protists, related to haptophyte algae within the supergroup Haptista Cavalier-Smith,

2003 (Burki et al. 2016). Centrohelids are characterized by the presence of surface cytoskeletal

46 structures - siliceous scales or organic spicules, having an important diagnostic value.

47 Heterotrophic flagellates and heliozoans are widespread in different types of freshwater and marine biotopes and play an important role in functioning of the microbial food webs, that provide effective pathways for the transformation of matter and energy in aquatic ecosystems (Arndt et al. 
centrohelids and flagellates to the trophic structure and functioning of aquatic ecosystems is also

52 probably very important, but not fully understood.

Faunistic investigations of heterotrophic flagellates and heliozoans supported with morphological descriptions were especially common in protistological literature in the 90s - early 2000s (Larsen and Patterson 1990; Lee and Patterson 2000; Lee et al. 2003; Mikrjukov 2001; Patterson and Simpson 1996; Patterson et al. 1993; Tong 1997b, c; Vørs 1992). Such studies have fallen from favour, and their scientific importance is often undeservedly disregarded, having been largely replaced by molecular surveys from bulk microbial community DNA (Geisen et al., 2019; Pawlowski et al., 2016). However, several recent advances in the study of eukaryotic evolution have been specifically tied to morphological identification of flagellates and heliozoans in the natural samples, their isolation inculture, and genomic and ultrastructural investigations from those cultures. Morphological recognition and identification (sometimes raw and approximate) of these protists in samples is precisely based on such "classical" studies, and would not have been possible without them. For example, recent recognition, isolation and investigation of previously understudied or unknown heterotrophic flagellates were essential in addressing major evolutionary problems, such as the origins of photosynthesis and parasitism and the trajectory of plastid spread (Gawryluk et al. 2019; Janouškovec et al. 2015; Tikhonenkov et al. 2020b), origin of multicellular animals (Hehenberger et al. 2017; Tikhonenkov et al. 2020a), evolution of mitochondrial genomes, rooting of the tree of eukaryotes and clarification of their relationships (Janouškovec et al. 2017; Lax et al. 2018; Strassert et al. 2019). Identification and establishing of clonal cultures of centrohelids were crucial for transcriptomic research and untangling the early diversification of eukaryotes (Burki et al. 2016).

Descriptions of many flagellates and heliozoans were made in the late XIX and early XX centuries using imperfect light microscopy: many of these species lack type material, ultrastructural, and molecular data, and the taxonomy of many species and groups is in need of revision (Lee et al. 2003; Schoenle et al. 2020). Currently, the described diversity of these protists 
represents only a small fraction of their total species richness in nature (Cavalier-Smith and von der Heyden 2007; Corliss 2002). Metagenomic and metabarcoding sequencing of environmental samples has revealed several lineages representing high levels of hidden diversity: e.g. ribogroups MALV, MAST, MAOP, MAFO, deep-sea pelagic diplonemids (DSPD), or eupelagonemids (del Campo and Ruiz-Trillo 2013; del Campo et al. 2015; Guillou et al. 2008; Massana and PedrósAlió 2008; Okamoto et al. 2019; de Vargas et al. 2015), as well as great variety of small new phylogenetic lineages associated with almost all large eukaryotic groups (del Campo et al. 2016; Keeling and del Campo 2017). New species of flagellates and centrohelids are constantly being discovered, which is indicative of a poor state of exploration and insufficient sampling.

At the same time, the questions about geographical distribution of protists are subject to lively, but stubbornly unresolved debate (Azovsky et al. 2016). Are protists species widespread around the globe, or is their distribution, like those of macroorganisms, more governed by the rules of historical biogeography? There are two alternative points of view on this issue: the Ubiquity Model (Fenchel and Finlay 2004; Finlay et al. 1996) and Moderate Endemicity Model (Foissner 2004, 2008). Additional data is needed to resolve this issue, especially in those regions on the planet that remain unexplored.

Here we describe a microscopical investigation of the species diversity of heterotrophic flagellates and centrohelid heliozoans in marine waters of coast of Curacao, which has not specifically been investigated previously. For the Caribbean Sea in general, only seven species of choanoflagellates were known (Thomsen and Østergaard 2019) until recent. We find the diversity of heterotrophic protists on Curacao to be rich and intriguing, including the presence of species potentially important for clarifying previously puzzling evolutionary and ecological questions. For example, the recently described colonial flagellate Choanoeca flexa, whose discovery and description from Curacao significantly contributed to the understanding of the origin of polarized cell contractility in animals (Brunet et al. 2019). We describe a survey of light and electron microscopical studies of the diversity of heterotrophic flagellates and centrohelid heliozoans from 
103 marine waters of several locations on Curacao, and provide micrographs and morphological

104 descriptions of observed species, as well as discussing their distribution and potential importance.

105

106

107

108

109

110

111

112

114

\section{MATERIALS AND METHODS}

Marine water samples were taken from eight locations around the island of Curacao in

April 2018. Samples came from several biotopes (from the surface of corals and sponges,

Sargassum algae wrings, sand, coral sand, and water column) both nearshore and at depths of $12-$ $25 \mathrm{~m}$ (detailed descriptions of sampling points are given in the Table). From each biotope, several replicates were taken, which were subsequently summarized. A total of 52 samples were investigated microscopically. Water temperature in the studied region is relatively constant, about 26-29 ${ }^{\circ} \mathrm{C}$. Samples were placed into $50 \mathrm{ml}$ plastic tubes and transported to the laboratory at $4^{\circ} \mathrm{C}$.

Samples were enriched with a suspension of Pseudomonas fluorescens Migula, 1895 bacteria and placed in Petri dishes. Samples were kept at $22^{\circ} \mathrm{C}$ in the dark and observed for 10 days to reveal the cryptic species diversity (Tikhonenkov et al. 2008; Vørs 1992). A culture of the kinetoplastid flagellate, Procryptobia sorokini (Zhukov, 1975) Frolov et al., 2001, was used as a food source for predatory heliozoans and flagellates.

An AxioScope A1 light microscope (Carl Zeiss, Germany) with DIC and phase contrast and water immersion objectives (total magnification $\times 1120$ ) was used for observations of living cells. Electron microscope preparations were carried out according to described methods (Mikrjukov 2002; Moestrup and Thomsen 1980) and observed in a JEM-1011 (Jeol, Japan) transmission electron microscope and a JSM-6510 LV (Joel, Japan) scanning electron microscope. The dendrogram showing the similarity of types of biotopes by flagellates' species composition was drawn on the basis of the Dice similarity index using the paired group algorithm in the PAST software package (Hammer et al. 2001).

The analysis of geographic distribution of heterotrophic flagellates was based on “morphospecies" concept (Fenchel and Finlay 2006; Finlay et al. 1996) and carried out using the 
129 previously published database (Azovsky et al., 2016, 2020) and available literature sources. Only

130 morphology-based (or morphology-confirmed) data were considered.

RESULTS

Eighty-six species and forms of heterotrophic flagellates and three species of centrohelid

134 heliozoans were observed, all of them are listed below systematically. A system of asterisks was

135 used to identify higher levels of taxonomic ranks (Order, sub-order, Super Family, Family, etc.)

136 per Adl et al. (2019). Morphological characteristics of most unusual and rare species of flagellates

137 and all centrohelids are gived. For each species, sample points are presented in accordance with

138 the Table. Presumably cosmopolitan morphospecies, indicated with "c", was previously recorded

139 from all hemispheres (North, South, West, and East) and from equatorial, tropical or subtropical,

140 temperate, and polar regions.

AMORPHEA Adl et al., 2012

Obazoa Brown et al., 2013

*Apusomonadida Karpov et Mylnikov, 1989

Amastigomonas debruynei De Saedeleer, $1931^{\mathrm{c}}$ - observed in sample points 2e, 3a, 3c, 8a. observed in sample points $3 \mathrm{a}, 5 \mathrm{~b}, 8 \mathrm{~b}$.

150 length, 3.5-4.0 $\mu \mathrm{m}$ in width. Anterior flagellum is about the cell length, its basal part passes in the

151 sleeve, distal part is acronematic. Posterior flagellum is 4 times longer than the cell, along half-

152 length passes in the sleeve. Numerous granules are visible inside the cell. The cells move by

153 gliding, with anterior flagellum beating with a flicking motion. Observation based on description

154 of six cells in LM. 


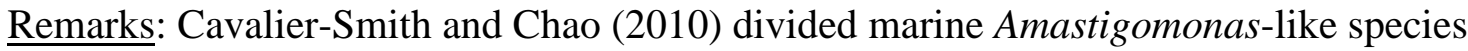

156 into four genera: Manchomonas, Multimonas, Podomonas, and Thecamonas. The last genus was

157 introduced earlier by Larsen and Patterson (1990) for biflagellate Amastigomonas-like protists

158 whose anterior flagellum and dorsal cell body surface are covered by a pliable organic theca. We

159 assigned species to the genus Thecamonas due to the presence of moderately rigid cell covering

160 (probably, theca). This ogranism differs from Manchomonas species by the presence of

161 acronematic flagella; one long posterior flagellum that extends beyond the ventral groove, and a

162 small and weakly noticeable triangular sleeve. We didn't observe multicellular plasmodia with

163 incomplete cytokinesis, as seen in Multimonas species, in Petri dishes over the course of 10 days

164 observation. Observed cells differed from Podomonas species by the absence of multiform finger-

165 like, lamellar or reticulose pseudopodia. Ultrastructural and molecular data are needed for

166 confirmation of position of this species within the genus Thecamonas.

167 Observed species differ from all known Amastigomonas-like species, except Podomonas

168 (=Amastigomonas) klosteris (Arndt et Mylnikov in Mylnikov, 1999) Cavalier-Smith in Cavalier-

169 Smith et Chao, 2010, because of the presence of long posterior sleeve surrounding the posterior

170 flagellum. However, Podomonas klosteris is characterized by larger cell body (length 12-20 $\mu \mathrm{m})$

171 with posterior sleeve that is shorter relative to the cell (about one quarter of the cell body length),

172 and presence of pseudopodia emerged from ventral groove (Mylnikov 1999).

$173 \quad *$ Opisthokonta Cavalier-Smith, 1987

174 **Holozoa Lang et al., 2002

$175 \quad * * *$ Filasterea Shalchian-Tabrizi et al., 2008

176 Ministeria vibrans Tong, $1997^{\mathrm{c}}$ (Fig. 1d-g) - observed in sample points 6, 8b.

177 Observations: Spherical cell body is $2.5-3.0 \mu \mathrm{m}$ in diameter, with $10-15$ radial thin

178 microvilli (arms) 4-5 $\mu \mathrm{m}$ in length. Cells attach to the substrate with a stalk (Fig. $1 \mathrm{~g}$ ) and make

179 fast pendulum movements with small amplitude (Fig. 1f). Sometimes cells stop moving for a 
180 while. Flagellates feed on bacteria, predominantly rod-like, that adhere to the surface of the cell

181 body. Nine cells observed in LM.

Remarks: Mylnikov and coauthors (Mylnikov et al. 2019) showed that Ministeria arms are

species differs from another member of the genus, M. marisola Patterson et al., 1998, by having a larger number of radial filopodia, as well as attachment to a substrate with a stalk and pendulum movements (Tong et al. 1997b).

191 Southern Chile, Tierra del Fuego (unpublished). cell and forming a small indentation. Lorica length is 5-6 $\mu \mathrm{m}$, width at the expanded anterior part is $4.5-5.5 \mu \mathrm{m}$. Cells obovoid, $4-5 \mu \mathrm{m}$ long, $3.0-3.5 \mu \mathrm{m}$ wide, with slightly expanded basal part and truncated anterior end. Collar length is 1-2 times longer than the cell, located mostly outside 
207 Lemmermann 1910; Starmach 1968; Tikhonenkov et al. 2008; Zhukov and Karpov 1985),

208 although Kent in the original description (1880) pointed out the heart-shaped morphology of the

209 lorica. The morphology of the cells we observed corresponded to the morphology described by

210 Kent. Sizes of cells are in agreement with previous descriptions, except length of flagellum in

211 observed cells is almost equal to cell length, while many authors noted flagellum length is 2.5

212 times longer than the cell.

213 Distribution: Fresh waters of European part of Russia (Kopylov et al. 2015; Tikhonenkov

214 and Mazei 2007), U.K. (Kent 1880), Hungary (Francé 1897), Poland (Starmach 1968). Black Sea

215 (Tikhonenkov 2006), Pechora Sea (Mazei and Tikhonenkov 2006; Tikhonenkov 2006).S. ringens

216 Kent, $1880-1882^{c}$ - observed in sample points $4 d, 5 b$.

217 S. ringens Kent, $1880^{\mathrm{c}}$ - observed in sample point $4 \mathrm{~d}, 5 \mathrm{~b}$.

218 S. tuba Kent, $1880-1882^{\mathrm{c}}-$ observed in sample point $3 \mathrm{~b}$.

Acanthoeca spectabilis Ellis, $1930^{\mathrm{c}}$ (Fig. 1k-n) - observed in sample point 7.

Observations: The living cell measured was $8.0 \times 4.5 \mu \mathrm{m}$, with rounded anterior end and tapered posterior end. Cells located in conical lorica $12.5-16.0 \mu \mathrm{m}$ in length. Lorica consist of rod-like costal strips. Posterior chamber is $8-9 \mu \mathrm{m}$ in length, $5.5-6.0 \mu \mathrm{m}$ in diameter, consist of numerous helically twisted costae. Lorica attached to the substrate with a long and thick stalk, 11$20 \mu \mathrm{m}$ in length, $0.4-0.6 \mu \mathrm{m}$ in diameter. Base of stalk expanded. Stalk consists of many rod-like costal strips oriented parallel to the longitudinal axis of the stalk and tightly adjacent to each other.

230 At the base of posterior chamber, the elements gradually twist into a spiral. Descriptions based on 231 observation of one living cell in LM and six loricae in TEM. 
Remarks: Morphology of observed lorica corresponds with previous descriptions, however,

233 some authors recorded other number of longitudinal costae: 10-16 (Leadbeater 1972), 13-15

234 (Leadbeater et al. 2008), 14 costae in original descriptions (Norris 1965). This species differs from

235 the second common species of the genus, A. brevipoda Ellis, 1930, by the presence of a stalk.

1973), Norway (Leadbeater 1972), USA (Norris 1965), Australia (Lee 2015; Lee et al. 2003; Tong

1997c; Tong et al. 1998), Taiwan (Hara et al. 1997), Antarctica (Marchant and Perrin 1990), Baltic

Sea (Vørs 1992). Hypersaline waters of Australia (Al-Qassab et al. 2002).

points $2 \mathrm{a}, 3 \mathrm{a}, 3 \mathrm{~b}, 6,7$.

Observations: Lorica is $10.6-14.7 \mu \mathrm{m}$ in length, consist of two chambers. Anterior chamber

is $6.6-9.2 \mu \mathrm{m}$ in length, $10.3-12.0 \mu \mathrm{m}$ in diameter, expands in the central part and tapers slightly

towards the mouth. Consist of 12-14 longitudinal costae and one double transversal costa (or two

transverse costae adjacent). Longitudinal costae consist of three rod-like costal strips, 3.4-4.9 $\mu \mathrm{m}$

in length, $0.15-0.20 \mu \mathrm{m}$ in diameter. Transversal costa of anterior chamber located closer to the

basal part of lorica, consist of many rod-like costal strips, overlapping each other. Posterior

chamber bell-shaped, often obscured by protoplast, 3.8-6.3 $\mu \mathrm{m}$ in length, $5.2-5.7 \mu \mathrm{m}$ in diameter,

Description based on records of one living cell in LM, and eleven loricae in TEM.

$\underline{\text { Remarks: }}$ Morphology of observed lorica corresponds with previous descriptions, however,

254 Thomsen and Østergaard (2019) indicated up to 18 longitudinal ribs. We recorded only 12-14

255 (often 14) ribs, which matches the original description, 10-14 longitudinal ribs in Hara et al.

256 (1996). This species close resembles A. apoda (Leadbeater, 1972) Hara et Takahashi, 1984 by the

257 presence of a double transverse rib, absence of stalk, as well as the presence of "empty space" 
258 between the transverse ribs of anterior and posterior chambers (Leadbeater 1972). However, $A$.

259 camarensis can be distinguished by shorter distance between anterior transverse costa and the

260 lorica waist (less than length of one longitudinal costal strip), and presence of additional helical

261 costal elements in posterior chamber (Thomsen and Østergaard 2019).

262 Distribution: Marine water of Hawaii, Thailand, Taiwan (Hara et al. 1996; Thomsen and

263 Østergaard 2019), Australia (Lee et al., 2003).

Stephanoeca apheles Thomsen, Buck et Chavez, $1991^{\mathrm{c}}$ - observed in sample points 3b, 6,

7.

Stephanoeca supracostata Hara in Hara et al., $1996^{c}$ (Fig. 2e-h) - observed in sample points 6,7 .

Observations: Living cells were not observed. Cells surround by basket-like lorica, consist

of siliceous costa. Lorica length (according to TEM and SEM whole mount) is $10.5-14.0 \mu \mathrm{m}$,

diameter in broad middle part is $7.5-8.0 \mu \mathrm{m}$. Lorica consist of anterior and posterior chambers.

Anterior chamber is 7.0-9.5 $\mu \mathrm{m}$ in length, includes $12-14$ longitudinal costae and three transversal costae. Longitudinal costae consist of two rod-like costal strips, connected to each other with a slight overlap. Anterior costal strips have flattened anterior tips, and posterior costal strips have flattened posterior tips. Anterior transversal costae located at the lorica mouth are 5-6 $\mu \mathrm{m}$ in

277 diameter. The second transversal costa is $4.5-5.5 \mu \mathrm{m}$ in diameter, located on the broadest part of 278 lorica, near the overlap of longitudinal costal strips. The third transversal costa is located at the 279 junction of anterior and posterior chambers. Posterior chamber is $4.0-4.5 \mu \mathrm{m}$ in length, tapers 280 conically to the basal end, and consist of numerous longitudinal costal strips with both tips flattened. Observation based on description of four loricae in TEM and one lorica in SEM. 
$284 \mu \mathrm{m}$ (Hara et al. 1996); number of longitudinal costae is 7-20 (Hara et al. 1996; Lee et al. 2003).

285 The morphology of the observed loricae is very similar to lorica of S. elegans (Norris, 1965)

286 Throndsen, 1974. Studied species can be distinguished from S. elegans by presence of third middle

287 transversal costa at the broadest lorica's part, as well as conically tapered posterior chamber. Other

288 species of Stephanoeca has more than three transversal costae.

289 Distribution: Marine waters of Australia (Lee et al. 2003), Taiwan, Japan (Hara et al.

290 1996), Thailand, Denmark (Thomsen and Østergaard 2019), U.K. (Tong 1997a).

291 Volkanus costatus (Valkanov, 1970) Özdikimen, 2009 - observed in sample points 3d, 6,

2927.

DIAPHORETICKES Adl et al., 2012

SAR Burki et al., 2008

*Alveolata Cavalier-Smith, 1991

**Colpodellida Cavalier-Smith, 1993

***Colpodellaceae Adl et al., 2019

298

Colpodella sp. - observed in sample point 6.

***Colponemida Cavalier-Smith 1993

Colponema marisrubri Mylnikov et Tikhonenkov, 2009 - observed in sample point 3c.

*Rhizaria Cavalier-Smith, 2002

**Cercozoa Cavalier-Smith, 1998 

perpetuity. It is made available under aCC-BY-ND 4.0 International license.

310 sample point 6. P. verrucosa (Larsen et Patterson, 1990) Cavalier-Smith in Howe et al., 2011 ${ }^{\mathrm{c}}$ - observed

312 in sample point 7.

makes flicking movements from anterior to lateral direction. Posterior flagellum is twice as long as flagellum.

Tikhonenkov and Mazei 2013). Cyranomonas sp. - observed in sample point 6. ****Variglissida Cavalier-Smith, 2014 
Observations: Cells are circular in outline, dorso-ventrally flattened, with slightly concave

335

336

ventral surface and anterior-medial depression. Cell diameter is 9-13 $\mu \mathrm{m}$. Two unequal nonacronematic flagella emerge from ventral depression and both directed posteriorly. Long flagellum is 2.0-2.3 times longer than the cell, and trailed behind the cell. Short flagellum is $2.5-3.0 \mu \mathrm{m}$ in length, immobile, and slightly thinner than the long flagellum. It is weakly visible during normal cell movement (Fig. 2l) and can be noticed when cells rise above the substrate (Fig. 2m).

Pseudopodia were not observed. Four cells were observed in LM.

$\underline{\text { Remarks: }}$ Morphology of observed cells corresponds with original description (Chantangsi and Leander 2010), at the smaller end of the size range indicated by authors. This species distinguishable from other species of the genus Clautriavia by presence of second short flagellum and circular cells in outline. Feeds on algae through the ventral side of the cell (Chantangsi and Leander 2010).

Distribution: Marine waters of British Columbia, Canada (Chantangsi and Leander 2010). ****Silicofilosea Adl et al., 2005 *****Thaumatomonadida Shirkina, 1987 ******Thaumatomonadidae Hollande, 1952

Thaumatomonas seravini Mylnikov et Karpov, $1993^{\mathrm{c}}$ (Fig. 3a-c) - observed in sample point $5 b$.

Observations. Living cells were not observed. According to TEM whole mount, protoplast is ovate, $6.5-7.5 \mu \mathrm{m}$ long and $4.5-6.0 \mu \mathrm{m}$ wide. Long flagellum is $20-23 \mu \mathrm{m}$ in length, short flagellum wasn't observed. Cells covered by numerous siliceous scales of one type. Scales consist of two triangular plates, connected to each other with three hollow cylindrical struts at the corners (0.2-0.3 $\mu \mathrm{m}$ in length). Sides of plates are about $0.5-0.6 \mu \mathrm{m}$ in length. Inner plate textureless, with more rounded corners. External plate with gently curved and more pointed corners and row of perforations along margin. A large oval hole located in each corner. Observations based on description of scales of five cells in TEM. 

perpetuity. It is made available under aCC-BY-ND 4.0 International license.

$\underline{\text { Remarks: }}$ This species is common in freshwater, but is extremely rare in marine waters (see

361 distribution). Our observations are corresponded with previous findings, except authors describe

362 larger sizes of the cell: length is $8.4-15.0 \mu \mathrm{m}$, width is 5.0-13 $\mu \mathrm{m}$ (Mylnikov and Karpov 1993;

363 Mylnikov et al. 2002, 2006; Prokina et al. 2017; Tikhonenkov 2006). Cell protoplasts could shrink

364 when dried. Size and morphology of observed scales are similar to described previously. This

365 species is quite similar to T. hindoni (Nicholls, 2013) Scoble et Cavalier-Smith, 2014, described

366 from fresh waters of Canada (Nicholls 2013). T. seravini differs from T. hindoni by larger

367 perforations along plate margins, presence of a large oval hole at each corner of external plate, and

368 more gentle curved corners (Mylnikov and Karpov 1993; Nicholls 2013; Scoble and Cavalier-

369 Smith 2014b). Another species of the genus Thaumatomonas with similar scales is T. zhukovi

370 Mylnikov, 2003, can be distinguished by the presence of two types of scales - oval and triangular.

371 However, Scoble and Cavalier-Smith (2014b) studied the morphology and 18S rRNA sequences

372 of several clones of this species and found that this species can be polymorphic with two or one

373 type of scales (either oval or triangular), so these species cannot be distinguished by the

374 morphology of scales with $100 \%$ certainty. Their studies also have shown that both species are

375 closely related.

376 Distribution: Fresh waters of European part of Russia (Kopylov et al. 2015;Mylnikov and

377 Karpov 1993; Mylnikov et al. 2002, 2006; Prokina et al. 2017; Tikhonenkov 2006), Mongolia

378 (Kopylov et al. 2006), Chile (Prokina and Mylnikov 2018), China (Tikhonenkov et al. 2012). Soils

379 of China (Tikhonenkov et al. 2012). White Sea (Tikhonenkov 2006; Tikhonenkov and Mazei

380 2013).

381

382

Metopion fluens Larsen et Patterson, $1990^{c}$ - observed in sample points 2a, 2b, 3c, 4b, 5b,

$5 \mathrm{c}, 6,7,8 \mathrm{a}$. 

perpetuity. It is made available under aCC-BY-ND 4.0 International license.

M. simplex (Griessmann, 1913) Larsen et Patterson, $1990^{\mathrm{c}}$ - observed in sample points 2a,

386

387

388

389

390

391

392

393

394

395

396

397

398

399

400

401

402

403

404

405

406

407

408

409

410

$2 b, 7$.

***Granofilosea Cavalier-Smith et Bass, 2009

*****Massisteridae Cavalier-Smith, 1993

Massisteria marina Larsen et Pattersen, $1990^{c}$ - observed in sample points 2a, 4d, 5b.

***Glissomonadida Howe et Cavalier-Smith, 2009

**** Dujardinidae Howe et Cavalier-Smith, 2011

****Allapsidae Howe et Cavalier-Smith, 2009

Allantion tachyploon Sandon, $1924^{\mathrm{c}}$ - observed in sample point $3 \mathrm{a}$.

Incertae sedis Cercozoa

Discocelis punctata Larsen et Patterson, $1990^{c}$ - observed in sample points 5 b, 7.

*Stramenopiles Patterson, 1989

**Bigyra Cavalier-Smith, 1998

***Opalozoa Cavalier-Smith, 1991

****Bicosoecida Grasse, 1926

Bicosoeca gracilipes James-Clark, $1867^{\mathrm{c}}$ - observed in sample point $2 \mathrm{~b}$.

B. maris Picken, $1841^{\mathrm{c}}-$ observed in sample points $1 \mathrm{~b}, 8 \mathrm{~b}$.

Caecitellus parvulus (Griessmann, 1913) Patterson et al., 1998 ${ }^{\mathrm{c}}$ - observed in sample

points $2 \mathrm{a}, 2 \mathrm{e}, 4 \mathrm{~d}, 5 \mathrm{c}, 6,7,8 \mathrm{~b}$.

Cafeteria ligulifera Larsen et Patterson, $1990^{c}$ - observed in sample points 3a, 4a, 5b, 6.

C. minuta (Ruinen, 1938) Larsen et Patterson, $1990^{c}$ - observed in sample points 4d, 5c.

C. roenbergensis Fenchel et Patterson, $1988^{\mathrm{c}}$ - observed in sample points $2 \mathrm{a}, 2 \mathrm{~b}, 2 \mathrm{c}, 3 \mathrm{a}$,

$3 b, 4 a, 4 b, 5 a, 5 b, 5 c, 6,7$.

Halocafeteria seosinensis Park et al., 2006 - observed in sample point 8b.

Pseudobodo tremulans Griessmann, $1913^{\mathrm{c}}$ - observed in sample point 6.

**Gyrista Cavalier-Smith, 1998 

perpetuity. It is made available under aCC-BY-ND 4.0 International license.

****ochrophyta Cavalier-Smith, 1986

*****Diatomista Derelle et al., 2016

*****Dictyochophyceae Silva, 1980

******Pedinellales Zimmermann et al., 1984 observed in sample point $3 \mathrm{a}$.

Paraphysomonas foraminifera Lucas, $1967^{\mathrm{c}}$ (Fig. 3d-f) - observed in sample points 3b, 6 . clearly visible. Shaft is $1.9-3.0 \mu \mathrm{m}$ in length, $0.05-0.1 \mu \mathrm{m}$ in diameter, with sharp end. Several single scales and scale aggregations of two cells observed in TEM.

433 (LeRoi and Hallegraeff 2006; Tong 1997c), and "sholders" - sharp narrowing of diameter of the 434 shaft in the middle of its length (Tong 1997c). This species differs from others by presence of $7-$ 10 concentric rows of holes on base plate and shaft without perforations on its basal part. Nicholls 
437 However, these scales probably belong to several Paraphysomonas or Clathromonas species

438 because of significant differences: presence of perforations on the basal part of shaft, as well as

439 reduced shaft on some scales, larger size of scales (base up to $2.5 \mu \mathrm{m}$ ). Several scales (Nicholls

440 1981: Fig. 16-18, p. 134) are very similar to scales of species Clathromonas takahashii (Cronberg

441 et Kristiansen, 1981) Scoble et Cavalier-Smith, 2014 and one scales (Nicholls 1981: Fig. 19, p.

442 134) are very similar to scales of Clathromonas elegantissima (Kling et Kristiansen, 1983) Scoble

443 et Cavalier-Smith, 2014.

445 (Bergesch et al. 2008), Canada (Smith and Hobson 1994), Australia (LeRoi and Hallegraeff 2006;

446 Tong 1997c; Tong et al. 1998), Greenland (Vørs 1993), Baltic Sea (Vørs 1992), Mediterranean

447 Sea (Throndsen and Zingone 1994).

$448 \quad$ Paraphysomonas sp. (Fig. $3 \mathrm{~g}-\mathrm{i}$ ) - observed in sample point $3 \mathrm{~d}$.

449 Observations: Living cells were not observed. Cells are covered by siliceous hobnail-like

450 scales of one type. Scales consist of circular flattened base and cylindrical shaft. Base is 0.6-0.9

$451 \mu \mathrm{m}$ in diameter, with a dense middle annulus. Shaft is $1.3-1.9 \mu \mathrm{m}$ in length, $0.08-0.1 \mu \mathrm{m}$ in

452 diameter, conically pointed into a rounded tip. Scales of two cells observed in TEM.

453 Remarks: Scales of this species are most similar to scales of $P$. imperforata Lukas, 1967 by

454 small length of shaft, base plate with middle annulus, and lacking dense margins. But observed

455 scales are differentiated by a noticeably thinner shaft without conical tapering. Other species with

456 middle annulus on base plate ( $P$. acuminata acuminata Scoble et Cavalier-Smith, 2014; $P$.

457 acuminata cuspidata Scoble et Cavalier-Smith, 2014; P.mikadiforma Scoble et Cavalier-Smith,

458 2014; P. hebetispina hebetispina Scoble et Cavalier-Smith, 2014) differ due to a very long shaft

459 relative to base plate diameter (Scoble and Cavalier-Smith 2014a).

$460 \quad$ Cryptista Adl et al., 2018

461

*Cryptophyceae Pascher, 1913

462

**Cyathomonadacea Pringsheim, 1944 

perpetuity. It is made available under aCC-BY-ND 4.0 International license.

Goniomonas pacifica Larsen et Patterson, $1990^{c}$ - observed in sample points 2a, 3d, 6, 7. G. truncata (Fresenius, 1858) Stein, $1878^{c}$ - observed in sample points 2a, 2d, 3b, 4d, 5c,

6,7 .

Goniomonas sp. - observed in sample point 8a.

type. Scales are 5.9-8.1 $\mu \mathrm{m}$ in length, that are slightly widened in the central part $(0.5-0.8 \mu \mathrm{m})$ and gradually taper to the poles (where they are $0.3-0.4 \mu \mathrm{m}$ ), forming circular poles $0.5-0.6 \mu \mathrm{m}$ in width. The length to width ratio is $8.2-13.8$. Inner surface of scales is smooth, without a longitudinal rib. Hollow marginal rim is $0.1-0.2 \mu \mathrm{m}$ in diameter in the middle, and expands to the poles. Scales of one cell were observed in SEM. elongated shape and circular poles, the lack of reticular structure on the inner surface of scales, and the absence of spine scales. 

perpetuity. It is made available under aCC-BY-ND 4.0 International license.

Base is $1.1-1.7 \mu \mathrm{m}$ in diameter, with a small notch. Tangential oval plate scales are $1.5-2.5 \times 1.5-$ $2.0 \mu \mathrm{m}$, with concave long sides and an axial ridge located inside medial depression. We observed scales of four cells in TEM.

Remarks: The size of observed scales corresponds with scales of subspecies $C h$.

Shatilovich et al. 2010), however, there are records with a length 8-10 $\mu \mathrm{m}$ (Leonov and Mylnikov 2012). Also, we previously described textureless plate scales, without axial ridge (Prokina and Mylnikov 2019).

510 Siberia, Russia (Shatilovich et al. 2010). Marine waters of Antarctica (Croome et al. 1987). Baltic

511 Sea (Vørs 1992). Saline inland waters of European part of Russia (Ermolenko and Plotnikov 2013). 

perpetuity. It is made available under aCC-BY-ND 4.0 International license.

Heterophrys-like organism (Fig. $4 \mathrm{~h}-\mathrm{j})$ - observed in sample point 5c.

$517 \quad 0.05-0.1 \mu \mathrm{m}$ in wide. Spicules are slightly flattened and spirally twisted along the longitudinal

518 axis, and both tips are pointed. Basal part of spicules immersed in mucopolysaccharide capsule

519 that is sometimes visible in TEM, as are axopodia. Spicules of five cells were observed in TEM.

520 Remarks: Centrohelids with spindle-shaped organic spicules have previously been found

521 from various freshwater and marine habitats around the world, and have been identified as species

522 of genera Heterophrys, Marophrys, and Sphaerastrum (Cavalier-Smith and von der Heyden 2007;

523 Mikrjukov 2002). However, recent studies have revealed close relations between spicule-bearing

524 Heterophrys-like organisms and siliceous scales-bearing species both by molecular data (18S

525 rDNA gene similarity of Polyplacocystis and Heterophrys), and by morphological data:

526 intermediate polymorphic stages of the life cycle of Raphidiophrys, bearing both siliceous scales

527 and organic spicules (Zlatogursky 2016; Zlatogursky et al. 2018). Based on these observations,

528 Zlatogursky with coauthors (Zlatogursky et al. 2018) suggested dimorphism of centrohelid life

529 cycle with two stages, one with siliceous scales and another with organic spicules. Thus, spicules

530 of the cells we studied may be the stage of the life cycle of one or more scale-bearing centrohelid

531 species.

Incertae sedis Diaphoretickes

Telonema subtile Griessmann, $1913^{\mathrm{c}}$ - observed in sample point $2 \mathrm{~b}, 6$.

536 Simpson, 2003]

*Discoba Simpson, 2009 

perpetuity. It is made available under aCC-BY-ND 4.0 International license.

542 in sample points $2 \mathrm{a}, 2 \mathrm{~b}, 2 \mathrm{~d}, 3 \mathrm{a}, 3 \mathrm{~b}, 5 \mathrm{~b}$.

543 ****Metakinetoplastina Vickerman, 2004 *****Neobodonida Vickerman, 2004 Neobodo designis (Skuja, 1948) Moreira et al., 2004 ${ }^{\mathrm{c}}$ - observed in sample points 2a, 2c, 2d, 3a, 3b, 4a, 4b, 5b, 6, 7, 8a. N. saliens (Larsen et Patterson, 1990) Moreira et al., 2004 ${ }^{\mathrm{c}}$ - observed in sample points 2a, $3 a, 4 b, 5 b, 6,8 a$. Rhynchobodo simius Patterson et Simpson, $1996^{\mathrm{c}}$ - observed in sample point 6. ***Euglenida Butschli, 1884 *****Heteronematina Leedale, 1967 Dinema platysomum (Skuja, 1939) Lee et Patterson, 2000 - observed in sample points 6. sample points $2 \mathrm{a}, 2 \mathrm{~b}, 5 \mathrm{~b}, 5 \mathrm{c}, 6,7$. 2a, 6, 7 . 1a, 1b, 3a. openings of flagellar pocket (Fig. 5a). Cell length is $9.5-14.0 \mu \mathrm{m}$, width is $6-9 \mu \mathrm{m}$. Single

563 flagellum is about the cell length or slightly longer, directed anteriorly. Dorsal side of the cell with 5646 gentle ridges (Fig. 5b), ventral side with two slightly noticeable ridges. Flagellar pocket at the 565 right side of the cell. Nucleus located in the anterior part of the cell. Observations based on four 566 cells found in LM. 

perpetuity. It is made available under aCC-BY-ND 4.0 International license.

$\underline{\text { Remarks: }}$ Our observations completely correspond with previous descriptions of this

568

569

570

571

572

573

574

575

576

577

578

579

580

581

582

583

584

585

586

587

588

589

590

591

592 species. Cell length is $16 \mu \mathrm{m}$ (Larsen and Patterson 1990) and 9.2-15.5 $\mu \mathrm{m}$ in the original description (Cann and Pennick 1986). The other species of the genus Petalomonas all have oval cell outlines (P. poosilla, P. ingosus Lee et Patterson, 2000, P. labrum Lee et Patterson, 2000, P. minor, P. minuta, P. tricarinata Skuja, 1939, P. vigatus Lee et Patterson, 2000), and differ in number or noticeability of dorsal and ventral ridges, or by the presence of a smooth cell surface. Distribution: Marine waters of U.K. (Cann and Pennick 1986), Brazil (Larsen and Patterson 1990).

P. minor Larsen et Patterson, $1990^{\mathrm{c}}$ - observed in sample points 1b, 2a, 3a, 6, 7 . P. minuta Hollande, $1942^{\mathrm{c}}$ - observed in sample points 5a, 5b, 6, 7 . P. ornata Skvortzov, $1957^{\mathrm{c}}-$ observed in sample point $3 \mathrm{~d}$. P. poosilla (Skuja, 1948) Larsen et Patterson, 1990 - observed in sample points 2a, 3a, 3b, $4 d, 5 a, 5 b, 6,7,8 b$.

Petalomonas sp. - observed in sample point 3c.

Ploeotia adhaerens Larsen et Patterson, $1990^{c}$ (Fig. 5d-f) - observed in sample points 6, 7. Observations: Cells not flattened, almost circular in outline, with four prominent dorsal ridges, two lateral ridges, and two ventral ridges. Posterior end of the cell is slightly extended into a small protrusion. Cell length is $26-30 \mu \mathrm{m}$, width is $22-27 \mu \mathrm{m}$. Anterior flagellum in about half of the cell length. Posterior flagellum is about 2.5 time longer than the cell, and noticeably thicker than the anterior flagellum. Flagellar pocket is situated on the left side of the cell and the nucleus on the right side. Cells contains large food vacuoles in their posterior half. Well-marked ingestion organelle with two rods located on the right side, and broad anteriorly. Observed seven cells in LM.

$\underline{\text { Remarks: }}$ Morphology of observed cells corresponds with previous descriptions, except longer anterior flagellum (equal to the cell length) and shorter posterior flagellum (about 1.5 times longer than the cell length) (Ekebom et al. 1995/6; Larsen and Patterson 1990). This species is 
593 594 prominent ridges.

easily distinguished from other Ploeotia species by almost round cells in outline and very

Distribution: Marine waters of Australia (Ekebom et al. 1995/6), Fiji (Larsen and Patterson 1990), Red Sea (Tikhonenkov 2009). Fresh waters of European part of Russia (Tikhonenkov 2006; Tikhonenkov and Mazei 2007).

P. aff. costata (Triemer, 1986) Farmer et Triemer, $1988^{c}$ - observed in sample point 7. P. discoides Larsen et Patterson, $1990^{c}$ - observed in sample points $5 \mathrm{~b}, 7$. P. oblonga Larsen et Patterson, $1990^{\mathrm{c}}$ - observed in sample points $2 \mathrm{a}$, $8 \mathrm{a}$. P. punctata Larsen et Patterson, 1990 - observed in sample point 3a. Ploeotia robusta Larsen et Patterson, 1990 (Fig. 5g-i) - observed in sample point 3b. Observations: Cells oval in outline, with subapically pointed posterior end (Fig. 5h). Cell length is $30-35 \mu \mathrm{m}$, cell width is $20-22 \mu \mathrm{m}$. Flagellar pocket opened subapically and covered laterally by lip-like flange (Fig. 5h). Anterior flagellum is about the cell length. Posterior flagellum is 3.5 times longer than the cell, and wider than anterior flagellum. One well-developed ventral groove extends from lip-like structure to the posterior pointed tip (Fig. 5i), and about 4-5 slightly noticeable grooves situated on both ventral and dorsal sides of the cell (Fig. 5g). Well-marked ingestion organelle with two gradually narrowing rods extends along entire cell length. Nucleus located at the left side of the cell. Posterior part of the cell contains a few food vacuoles. Cells lack any surface structure, except the ventral groove associated with lip-like flanges, and a rough surface. Four cells were found in LM.

Remarks: We observed about 8-10 poorly visible grooves on cell body surface, despite these not being part of the original description by Larsen and Patterson (1990). Patterson and Simpson (1996) also noticed at least eight delicate grooves arranged evenly around the cell body, which they described as being faintly visible and easily overlooked. At the same time, Al-Qassab with coauthors (2002) recorded 3-4 ventral ridges and 4-5 dorsal ridges. Patterson and Simpson (1996) described longer flagella, with the anterior flagellum twice as long as the cell and posterior 
619 flagellum 4 times the length of the cell. This species differs from other Ploeotia species by larger

620 cell size, presence of anterior-lateral lip-like flanges with extended well-developed ventral groove,

621 long posterior flagellum, and posterior pointed end of the cell.

622 Distribution: Marine waters of U.K., Hawaii (Larsen and Patterson 1990). Hypersaline

623 water of Australia (Al-Qassab et al. 2002; Patterson and Simpson 1996).

$624 \quad$ Ploeotia sp. 1 - observed in sample points 2a, 5a, 5b, 5c. ***Diplonemea Cavalier-Smith, 1993 2c, 5 b. outline during turns (Fig. 51). Cells are 14.5-16 $\mu \mathrm{m}$ long, 4-6 $\mu \mathrm{m}$ wide, elliptical with slightly ingestion organelle seen during metaboly (Fig. 5l, m). Cell surface is bumpy. Only gliding cells were observed. Observations based on findings of six cells in LM. except that shorter flagella were described by Larsen and Patterson (1990), 3-4 $\mu \mathrm{m}$; and longer flagella were described by Tong (1994, 1997b), $8 \mu \mathrm{m}$. Also, Tong (1994) noted that one flagellum sometimes can wraps around the cell, but we did not observe this. Other known species of this genus, D. breviciliata Griessmann, 1914, and D. metabolicum Larsen et Patterson, 1990, can be

6432018 and D. japonicum Tashyreva et al., 2018 can be distinguished by broader anterior part of the 644 cell and narrowed anterior end, as well as presence of a sessile rounded cell stage and swimming 
645 stage with unequal flagella twice the length of the cell (Tashyreva et al. 2018); D. papillatum

646 (Porter, 1973) Triemer et Ott, 1990 can be distinguished by oval to almost round outline of cells,

647 the presence of prominent apical papilla, and very short, thick flagella (Porter 1973). Morphology

648 of studied species is similar to Rhynchopus amitus by its cell size and shape, but latter species can

649 be distinguished by presence of flagella that are thicker, barely emerge from flagellar pocket,

650 curve posteriorly, and are mostly motionless (Al-Qassab et al. 2002; Tong et al. 1998), see below.

651 Distribution: Marine waters of Australia (Tong et al. 1998), Brazil (Larsen and Patterson

652 1990), U.K. (Patterson et al. 1993; Tong 1994, 1997c).

Rhynchopus amitus Skuja, $1948^{c}$ (Fig. 5n, o) - observed in sample points 2a, 8b.

$654 \quad$ Synonym: R. conscinodiscivorus Schneps, 1994.

Observations: Cells sac-shaped, with rounded ends and fine anterior apical papilla. Cell

656 length is $9.5-12 \mu \mathrm{m}$, width is $4-5.5 \mu \mathrm{m}$. Cells very metabolic, periodically contracts. Flagellar

657 pocket opened below the apical papilla, directed anterior-laterally. Flagella usually do not emerge

658 from pocket. Numerous granules are visible inside the cell just below the cell surface. Cells glide

659 slowly, constantly change directions; swimming cells were not observed. Two cells were found in

660 LM.

661

$\underline{\text { Remarks: }}$ Most authors observed larger cells, up to $25 \mu \mathrm{m}$ (Al-Qassab et al. 2002; Lee,

662 2015; Schnepf 1994; Skuja 1948; Tong et al. 1998). Studied species differs from other species of

663 Rhynchopus by cell shape and size. R. euleeides Roy et al., 2007 differs by presence of long

664 unequal flagella in swimming cells (2.5 times longer than the cell), symmetric elliptical shape of

665 resting cells, clusters of many cells in culture (Roy et al. 2007). R. hemris Tashyreva et al., 2018

666 differs by both narrowed ends of the cell, swimming cells with one flagellum wrapped around

667 anterior part of the cell and wobbling like a lasso, and another flagellum extended along the cell

668 and waving (Tashyreva et al. 2018). R. serpens Tashyreva et al., 2018 has tapered anterior part of

669 the cell and broad posterior end, as well as larger cell size (Tashyreva et al. 2018). Observed

670 species is also similar to Diplonema ambulator (see above). 

perpetuity. It is made available under aCC-BY-ND 4.0 International license.

Distribution: Marine waters of Australia (Lee 2015; Lee et al. 2003; Tong et al. 1998),

672 Wadden Sea ([as R. conscinodiscivorus] Schneps 1994). Saline inland waters of Romania ([as

673 Menoidium astasia] Entz 1883). Hypersaline waters of Australia (Al-Qassab et al. 2002; [as

674 Menoidium astasia] Ruinen 1938). Fresh waters of Sweden (Skuja 1948).

675

**Heterolobosea Page et Blanton, 1985

676

677

***Tetramitia Cavalier-Smith, 1993

678

****Eutetramitia Hanousková et al., 2018

******Percolomonadidae Cavalier-Smith, 2008

679

Percolomonas cosmopolitus (Ruinen, 1938) Fenchel et Patterson, $1986^{\mathrm{c}}$ - observed in

680

sample points 1a, 7 .

681

P. denhami Tong, $1997^{\mathrm{c}}$ - observed in sample points $1 \mathrm{~b}, 2 \mathrm{a}, 2 \mathrm{c}, 5 \mathrm{~b}, 6$.

682

P. similis Lee et al., $2003^{\mathrm{c}}$ - observed in sample points 1a, $2 \mathrm{a}$.

683

Incertae sedis Eukarya: CRuMs

684

*“CRuMs” (Brown et al., 2018)

685

Glissandra innuerende Patterson et Simpson, $1996^{\mathrm{c}}$ - observed in sample point 6.

686

Incertae sedis Eukarya: CRuMs

687

688

*CRuMs" (Brown et al. 2018) [Varisulca Cavalier-Smith 2012] (R)

689

**Mantamonas Cavalier-Smith et Glücksman, 2011

690

Mantamonas plastica Glücksman et Cavalier-Smith in Glücksman et al., 2011 (Fig. 6a-c)

691

- observed in sample points $3 \mathrm{a}, 6,7$.

692 a changeable tail pseudopodium, connected with posterior flagellum. Left side of the cell is

693 smaller than right side. Cell length is $3.5-4.5 \mu \mathrm{m}$, width is $2.5-3.0 \mu \mathrm{m}$ at the broadest part.

694 Anterior flagellum is thin, directed laterally (to the left), and moves rarely. Length of anterior

695 flagellum is equal to the cell length. Posterior flagellum is about twice the length of the cell, 
696 thicker than the anterior flagellum, and trails behind the cell. Both flagella non-acronematic. Ten

697 cells were observed in LM.

Remarks: Size and morphology of observed cells are similar to those observed earlier,

except in original description authors noted acronematic posterior flagellum (Glücksman et al. anterior flagellum and flexible triangular shape of cells.

\section{Other incertae sedis Eukarya}

“Heterochromonas opaca” sensu Lee et Patterson, 2000 (Fig. 6d, e) - observed in sample point 6.

Observations: Oval cells with slightly narrowed ends and apical anterior protrusion. Cell

717 Patterson (2000) as "Heterochromonas opaca". However, despite the similar cell shape, the cell originally described as Heterochromonas opaca Skuja (1948) is probably a different organism. The genus Heterochromonas Pascher, 1912 was introduced for colourless chrysomonads without scales, related to Ochromonas Vysotskii, 1887, and, probably, a junior synonym of Spumella

721 Cienkowski, 1870 (Grossmann et al. 2016). Species of Heterochromonas are characteried by a 

perpetuity. It is made available under aCC-BY-ND 4.0 International license.

722 clearly stramenopile body plan, with non-flattened metabolic cells, truncated apically, and with

723 two unequal heterodynamic flagella, both directed anteriorly, and with small protoplasmic collar

724 around apical depression. Species Heterochromonas opaca, described by Skuja (1948) are

725 characterized by globular cells with well-developed amoeboid collar that can almost completely

726 disappear (except for the basal part), and the presence of short finger-like irregular pseudopodia

727 involved in the capture of food particles. The cell described by Lee and Patterson (2000) as

728 "Heterochromonas opaca" cannot be attributed to Chrysophyceae due to rigid and flattened cells

729 without an anterior collar and pseudopodia, or the long flagellum directed posteriorly and trailed

730 behind the cell. In addition, Skuja described freshwater species with 2-3 contractile vacuoles,

731 while "Heterochromonas opaca" sensu Lee et Patterson, 2000 was found only in marine waters

732 (see distribution). Thus, most likely Lee and Patterson described a completely different species,

733 probably new, that needs to be renamed and investigated to clarify its relationships with other

734 eukaryotes. According to the external morphology and movement, this organism could tentatively

735 be attributed to Euglenida.

736 Previously described cells from the Black Sea (Prokina et al. 2018), identified as

737 Heterochromonas opaca Skuja, 1948, are characterized by markedly different morphology:

738 circular cells in outline; poorly developed anterior protrusion; smaller cell sizes; greater length and

739 mobility of flagella. Probably it was another, undescribed species, related to "Heterochromonas

740 opaca" sensu Lee et Patterson, 2000.

741 Distribution: Marine waters of Australia (Lee and Patterson 2000), South Korea (Lee

742 2002).

743 “Protist 1" (Fig. 6f-j) - observed in sample point 7.

744 Observations: Rigid cells are either spherical or ovoid, with slightly flattened ventral side.

745 Cell length is $4.5-5.5 \mu \mathrm{m}$, cell width is $3.8-5.5 \mu \mathrm{m}$. Unequal non-acronematic flagella insert

746 subapically from ventral side. Anterior flagellum is about the cell length, directed mostly forward,

747 without moving, but can turn back when the cell turns (Fig. 6g, h). Posterior flagellum is about 
25-35 $\mu \mathrm{m}$ long, trailed behind the cell. Pseudopodia were not observed. Nucleus located medially.

749 Cells move slowly, gliding on the posterior flagellum. Four cells were observed in LM.

$\underline{\text { Remarks: }}$ Observed organism differed from other known flagellate species by presence of

the following morphological features: longer anterior flagellum which almost equal in length to anterior-laterally and beating always to left in a small excursion (Lee 2015).

“Protist 2" (Fig. 6k-p) - observed in sample point 7. the cell (Fig. 6m, n), which makes circular movements, potentially helping the cell move. Cells are located near a substrate and rotate around its axis. A stalk was not observed. Eleven cells were found in LM.

$\underline{\text { Remarks: }}$ Observed organism was frequently found in samples from the Black Sea and

769 White Sea (unpublished). We can not exclude the possibility of investigating a dividing or dying 770 cells of some known species. Very thin obscure flagellum also known for flagellate species

771 Ministeria vibrans (Mylnikov et al. 2019). Presence of longitudinal ventral groove is typical for 772 Jakobida Cavalier-Smith, 1993. Among Jakobida there are some species in the family Histionina 773 Cavalier-Smith, 2013, which also attaches to the substrate and has a very similar cell shape and 
size: Histiona aroides Pasher, 1942, H. velifera (Voigt, 1901) Pasher, 1943, Reclinomonas

775

776

777

778

779

780

781

782

783

784

785

786

787

788

789

790

791

792

793

794

americana Flavin et Nerad, 1993, and R. campanulata (Penard, 1921) Flavin et Nerad, 1993.

These species, however, differ by their possession of lorica and clearly observable flagella.

Aloricate Jakobids (such as Ophirina amphinema Yabuki et al., 2018, Andalucia godoyi Lara et al., 2006, Moramonas marocensis Strassert et al., 2016, etc.) are characterized by oval or beanshaped cells with thick visible flagella, as well as typically swimming cells, not attached to the substrate (Lara et al. 2006; Strassert et al. 2016; Yabuki et al. 2018).

"Protist 3" (Fig. 7a-e) - observed in sample point 3c.

Observations: Cell oval in outline, rigid, with rounded anterior end, narrowed posterior end, and convex dorsal side. Not metabolic. Cell length is $7.5-10.0 \mu \mathrm{m}$, cell width is $5.5-6.5 \mu \mathrm{m}$. The entire surface of the cell is covered with prominent tubercles. Flagella thick, non-acronematic, and insert apically from the anterior end of the cell. Anterior flagellum is $6.5-8.0 \mu \mathrm{m}$ in length, directed anteriorly, slightly curved to the dorsal side (forming an arc), and moving very little.

Posterior flagellum is $14-17 \mu \mathrm{m}$ in length, trailed behind the cell. Flagellates slowly glide or swim. Swimming cells vibrates together with the flagella, slowly rotates in different directions, with flagella keep the position like in gliding cells. Eight cells were examined in LM.

$\underline{\text { Remarks: }}$ Observed organism most similar to glissomonads (Allapsa, Sandona, Heteromita etc.) and ancyromonads (Ancyromonas, Planomonas) in shape and size of the cell. However, these species possess less rigid cells, and a smooth cell surface without tubercles. Also, none of these species have a fixed arc position of flagella.

"Protist 4" (Fig. 7f-j) - observed in sample points 2d, 6 .

Observations: Cell is $19.5-28.0 \mu \mathrm{m}$ in length, $8-11 \mu \mathrm{m}$ in width in the expanded part. Cells pear-shaped, highly metabolic, with posterior protoplasmic tail. Flagella inserts subapically from ventral protrusion. Anterior flagellum thin, slightly noticeable during cell motility, directed forward and undulating. Posterior flagellum thicker, vibrates with a constant amplitude of approximately $10 \mu \mathrm{m}$. Cells move slowly and swim in a straight line near the substrate, with a 
800 little trembling. Feeding behavior was not recorded, but probably food particles are captured by

801 the caudal or ventral pseudopodia. Specimens were noted both in hypersaline and marine biotopes, with no difference in morphology. Six cells were examined in LM.

805 feature: the basal part of the posterior flagellum passes inside the cell and emerge at the central 806 part of the body from the ventral opening. Species of the genus Tremula (T. longifila Howe et 807 Cavalier-Smith, 2011 and T. vibrans (Sandon, 1927) Cavalier-Smith, 2011) glide on the substrate 808 (Howe et al. 2011), while the studied organism was only observed swimming. Species of the genus 809 Aquavolon (A. dientrani Tikhonenkov, Mylnikov et Bass, 2018 and A. hoantrani Tikhonenkov,

810 Mylnikov et Bass, 2018) constantly rotate around the longitudinal axis of the cell during

811 swimming (Bass et al. 2018), while the studied organism swam straight. A similar manner of 812 movement has been described for the species Lapot gusevi Tikhonenkov, Mylnikov, Irwin et 813 Keeling, 2019 (Irwin et al. 2019), however, the latter is distinguished by a flattened cell and the 814 presence of few short wide pseudopodia extending from the entire surface of the cell. In addition,

815 known species of Lapot and Aquavolon were recorded only from freshwater.

816 "Protist 5" (Fig. 7k-q) - observed in sample point 2a.

818 width, with two acronematic flagella and anterior nucleus. Flagella inserts from the ventral groove 819 (depression) which begins just above the middle of the cell and goes obliquely to the posterior end 820 of the cell. Posterior flagellum longer than the anterior one, and both are longer than the cell.

821 Flagella and their beating are almost invisible when the cell is moving. Cells swim rapidly and 822 chaotically, always rotate in different planes, and change the direction of movement frequently.

823 Sated cells are wide-oval with prominent posterior food vacuole (Fig. 7k, m, n). Starved cells are 824 narrower, one side is more flattened and other is more roundish, with pointed posterior end (Fig. 825 71, p). Eight cells were examined in LM. 

perpetuity. It is made available under aCC-BY-ND 4.0 International license.

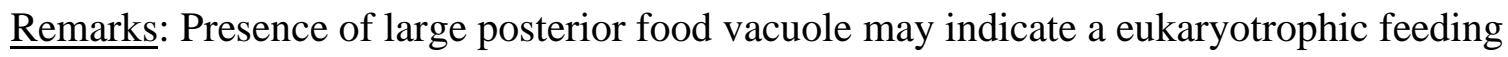

827 mode of this protist. Fast moving cells with ventral groove resemble colponemids, Acavomonas,

828 and Ancoracysta (Janouškovec et al. 2017; Tikhonenkov et al. 2014). But the latter are twice the

829 size and slower moving cells. Also, longitudinal grooves in colponemids and Ancoracysta do not

830 go obliquely. Starved cells resemble some jakobids and Cafeteria-like stramenopiles in body plan,

831 but their movement and behavior is absolutely different. Cells with planar ventral and convex

832 dorsal surface are similar to bacteriovorous Malawimonas and some Carpediemonas-like

833 organisms. But their flagella insert more anteriorly and are well defined. Also, Malawimonas

834 swims in a straight line and known only from freshwater (O’Kelly and Nerad 1993).

DISCUSSION

The morphology of many of the observed species was slightly different from previous

838 descriptions of any protist. Seven flagellate species were identified only to a genus level:

Thecamonas sp., Colpodella sp., Cyranomonas sp., Goniomonas sp., Petalomonas sp., Ploeotia

840 sp. 1, and Ploeotia sp. 2. These organisms may represent not yet described species of these genera,

841 but further studies are needed. Among the 86 heterotrophic flagellates and 3 centrohelids

842 encountered in this survey, five heterotrophic flagellates ("Protist 1", "Protist 2", "Protist 3",

843 "Protist 4", and "Protist 5") and one centrohelid heliozoan (Heterophrys-like organism) were not

844 identified even to the genus level. Of them, several of the flagellate protists have a unique

845 morphology and may represent undescribed lineages of even a high taxonomic level. From the

846 morphological perspective, we speculate that "Protist 1", "Protist 3", and "Protist 4" may be

847 unknown lineages of marine cercozoans. "Protist 5" (resembling Ancoracysta and colponemids)

848 and "Protist 2", which shows no significant similarity to known unicellular eukaryotes, may

849 represent unknown (perhaps deep) branches of the tree of eukaryotes. Several such "weird-

850 looking" protists have indeed recently been shown to represent new lineages (Janouškovec et al.

851 2017; Eglit, Simpson 2018; Eglit et al. 2017). The under-studied and puzzling Hemimastix 
852 similarly turned out to be a new, high-ranking phylogenetic lineage of eukaryotes (Lax et al.

853 2018). Predatory protists with Colponemid-like morphology and behavior are also very intriguing

854 and evolutionarily important, as they are falling in severaldifferent parts of the tree, and contribute

855 to the understanding of the origin of photosynthesis, parasitism, and evolution of mitochondrial

856 genome (Gawryluk et al. 2019; Janouškovec et al. 2013, 2017; Tikhonenkov et al. 2020).

857 The greatest number of identified flagellate species seem to be members of the SAR

858 supergroup (29 species), Excavates (27), and Obazoa (17). Lower number of flagellate species are

859 apparently members of Cryptista (3), "CRuMs" (2), and Ancyromonadida (1). Six species are of

860 the uncertain systematic position. Centrohelids fall into three families: Raphydocystidae (1

861 species), Choanocystidae (1), and Heterophryidae (1). All described protist species are new for

862 marine waters of Curaçao, as well as for the Caribbean Sea.

863 More than half of the identified species of heterotrophic flagellates (46 species, 63\%) and

864 all identified centrohelid heliozoans were previously recorded not only from marine, but also from

865 freshwater habitats and can be considered as euryhaline. Twenty-seven flagellate species (37\%)

866 were previously reported only from marine and saline inland waters: Acanthocorbis camarensis,

867 Acanthoeca spectabilis, Bicosoeca maris, Caecitellus parvulus, Clautriaviabiflagellata,

868 Colponema marisrubri, Cyranomonas australis, Diplonema ambulator, Discocelis punctata,

869 Clissandrainnuerende, Goniomonas pacifica, Halocafeteria seosinensis, Mantamonas plastica,

870 Massisteria marina, Metromonasgrandis, Paraphysomonas foraminifera, Percolomonas denhami,

871 P. similis, Petalomonascantuscygni, Ploeotia punctata, P. robusta, Protaspategere, Salpingoeca

872 infusionum, Stephanoeca cupula, S, diplocostata, S. supracostata, Volknus costatus.

873 The most frequent flagellate species in investigated sampling points were Ancyromonas

874 sigmoides, Cafeteria roenbergensis, Goniomonas truncata, Lentomonas azurina, Metopion fluens,

875 Metromonas grandis, Neobodo designis, Petalomonas poosilla, Pseudophyllomitus apiculatus,

876 and Rhynchomonas nasuta; they were found in more than $20 \%$ of observed samples. Thirty 
877 flagellates were rare and found only in one sample. Each of the three observed centrohelid species

878 was observed at only one sampling site.

879 The average number of species of flagellates and heliozoans in the studied samples is

880 relatively low, 7.0 and 0.1 respectively. Studied marine biotopes have a significantly greater

881 species diversity of flagellate species (total of 83 species, 7.2 on average), compared with

882 hypersaline biotopes, (total of 17 species, 5.0 on average). Common for both marine and

883 hypersaline waters were 15 flagellates: Amastigamonas debruynei, Ancyromonas sigmoides,

884 Bicosoeca maris, Caecitellusparvula, Ciliophrys infusionum, Metopion fluens, Ministeria vibrans,

885 Neobodo designis, N. saliens, Petalomonas poosilla, Ploeotia oblonga, Ploeotia sp. 2, Podomonas

886 griebenis, Rhynchomonas nasuta, and Rhynchopus amitus. Halocafeteria seosinensis and

887 Goniomonas sp. were found only in hypersaline habitats.

888 Among observed types of biotope, most flagellate species were found on surface of corals

889 (total of 57 species, on average -8.1 species per sample) and surface of sponges (39 and 7.2

890 respectively). These biotopes also were more similar in their species composition compare to other

891 types of habitats (Fig. 8). But the largest number of species in the sample on average was found in

892 coral sand (34 and 13.7). Lower total and average number of flagellate species found in sand

893 samples (24 and 3.9), water column (18 and 6.3), clay (8 and 4.5), and Sargassum algae wrings (2

894 and 2.0). Centrohelid heliozoans were observed only in scraping from sponge (Raphydocystis

895 bruni), sand (Heterophrys-like organism), and water column (Choanocystis perpusilla).

896 The vast majority (89\%) of taxa identified to the species level are characterized by a

897 generally wide geographical distribution, and have previously been recorded from all hemispheres

898 (North, South, West, and East), as well as from equatorial, tropical or subtropical, temperate, and

899 polar regions. These (morpho)species can be considered cosmopolites (marked with "c"). Seven

900 species were previously described only from two regions: Colponema marisrubri, Red Sea

901 (Tikhonenkov 2009) and Black Sea (Prokina et al. 2018); Halocafeteria seosinensis, Korea (Park

902 et al. 2006) and South of European part of Russia (Plotnikov et al. 2011; Prokina 2020); 
903 Petalomonas cantuscygni, Brazil (Larsen and Patterson 1990) and U.K. (Cann and Pennick 1986);

904 Ploeotia punctata, Australia (Al-Qassab et al. 2002; Larsen and Patterson 1990; Patterson and

905 Simpson 1996) and Hawaii (Larsen and Patterson 1990); Ploeotia robusta, Australia (Al-Qassab et

906 al. 2002; Patterson and Simpson 1996) and Hawaii (Larsen and Patterson 1990); Mantamonas

907 plastica, U.K. (Glücksman et al. 2011) and Australia (Lee 2015); “Heterochromonas opaca”,

908 Australia (Lee and Patterson 2000) and Korea (Lee 2002). Among the listed rare species, about

909 half (3) are relatively recently described (after 2000), and further surveys may expand data on their

910 distribution. One species, Clautriavia biflagellata, was previously described only once, from

911 Canada (Chantangsi and Leander 2010).

912 Among identified heliozoans, Choanocystis perpusilla was recorded from all hemispheres

913 and all above-listed climatic regions. Raphydocystis bruni also has been observed in

914 allhemispheres but only in temperate and tropical regions.

915 Nevertheless, the conclusions on geographical distribution of protists are highly dependent

916 on which species concept is applied (Azovsky et al. 2016). Here we followed the "morphospecies

917 concept". However, analysis of the ribosomal RNA genes of several common flagellate

918 morphospecies have shown that they can be represented by morphologically indistinguishable but

919 genetically different strains (von der Heyden and Cavalier-Smith 2005; Koch and Ekelund 2005;

920 Pfandl et al. 2009; Scheckenbach et al. 2006; Scoble and Cavalier-Smith 2014a). Some of these

921 strains appeared to be cosmopolitan, but others were not. In contrast, some benthic cercomonads,

922 the stramenopile Cantina, the craspedid choanoflagellate Codosiga, and several acanthoecid

923 species have all been shown to have no detected genetic divergence even between geographically

924 distant populations (Bass et al. 2007; Nitsche and Arndt 2015; Stoupin et al. 2012; Yubuki et al.

925 2015).

926 Many regions of the world remain insufficiently studied for flagellates and even more so

927 for heliozoans. Indeed, under-sampling is currently the key factor affecting our understanding of

928 protists diversity and distribution (Azovsky et al. 2020). To illustrate this, the species 
929 accumulation curve for studied Curacao samples (Fig. 9) fit well $\left(R^{2}=0.98\right)$ with power function

$930 S=9.36 N^{0.63}$. The curve does not flatten out (power coefficient is more than 0.5 ), so the species list

931 obtained for these sites in Curacao is far from being complete, and each new sample should yield 932 new species.

933 Undoubtedly, there are many species unaccounted for in each protist diversity survey, and

934 there are many unknown new species in natural ecosystems. Their discovery and description will

935 not only clarify our understanding of distribution patterns of microeukaryotes, but may also

936 contribute to resolving previously puzzling evolutionary and ecological problems. Our

937 observations from Curacao reveal many obscure species identified as "sp." or not identified at all.

938 Future work on these protists and molecular investigation in clonal cultures is very promising.

939 Successful isolation in culture largely depends on an understanding of their biology and feeding

940 mode, which can be clarified through observation in natural samples. Alternatively, single-cell

941 transcriptomics is a very efficient approach to study molecular diversity, biology, and the

942 functional state of even small sized protists (Gavelis et al. 2015; Ku and Sebé-Pedrós 2019; Liu et

943 al. 2017; Onsbring et al. 2019), which can be used for 'uncultivable' cells. Future discoveries and

944 investigations of flagellates observed but unidentified here, and other unusual protists, will

945 complement the known diversity and biogeography of microbial eukaryotes and can also advance

946 evolutionary research where these organisms represent new branches of the eukaryotic tree.

947

948

Author contributions

950 illustrations, writing of the original draft (KIP, DVT); statistical analysis (DVT); fieldwork and

951 supervision (DVT, PJK); funding acquisition (DVT, PJK); manuscript review and editing (PJK). 
This work was supported by grant from the Russian Foundation for Basic Research (grant

955

956

957

958

959

960

961

962

963

964

965

966

967

968

969

970

971

972

973

974

975

976

977

978

979

no. 20-34-70049) and carried out within the framework of the project no. AAAA-A18-

$118012690098-5$ of the Ministry of Education and Science of the Russian Federation. We thank

The Gordon and Betty Moore Foundation for travel support, Mark Vermeij and CARMABI research station for field sampling support, and Emma George for help with sample collection.

\section{REFERENCES}

Adl, S.A., Bass, D., Lane, C.E., Lukeš, J., Schoch, C.L., Smirnov, A., Agatha, S., Berney, C., Brown, M.W., Burki, F., Cardenas, P., Čepička, I., Chistyakova, L., del Campo, J., Dunthorn, M., Edvardsen, B., Eglit, Y., Guillou, L., Hampl, V., Heiss, A.A., Hoppenrath, M., James, T.Y, Karnkowska, A., Karpov, S., Kim, E., Kolisko, M., Kudryavtsev, A., Lahr, D.J.G., Lara, E., Le Gall, L., Lynn, D.H., Mann, D.G., Massana, R., Mitchell, E.A.D., Morrow, Ch., Park, J.S., Pawlowski, J.W., Powell, M.J., Richter, D.J., Rueckert, S., Shadwick, L., Shimano, S., Spiegel, F.W., Torruella, G., Youssef, N., Zlatogursky, V., Zhang, Q., 2019. Revisions to the classification, nomenclature, and diversity of eukaryotes. J. Eukaryot. Microbiol.66(1), 4-119.

https://doi.org/10.1111/jeu.12691

Al-Qassab, S., Lee, W.J., Murray, S., Simpson, A.G.B., Patterson, D.J.,2002. Flagellates from stromatolites and surrounding sediments in Shark Bay, Western Australia. Acta Protozool. 41, 91144.

Arndt, H., Dietriech, D., Auer, B., Cleven, E.-J., Grafenhan, T., Weitere, M., Mylnikov, A.P., 2000. Functional diversity of heterotrophic flagellates in aquatic ecosystems. In: Leadbeater, B.S.C., Green, J.C. (Eds.), The flagellates: Unity, diversity and evolution. Taylor and Francis, London and New York, pp. 240-268.

Aydin, E.E., Lee, W.J., 2012. Free-living heterotrophic flagellates from intertidal sediments of Saros Bay, Aegean Sea (Turkey). Acta Protozool. 51, 119-137.

https://doi.org/10.4467/16890027AP.12.010.0514 

perpetuity. It is made available under aCC-BY-ND 4.0 International license.

Azovsky, A.I., Tikhonenkov, D.V., Mazei, Yu.A., 2016. An estimation of the global

981 diversity and distribution of smallest eukaryotes: biogeography of marine benthic heterotrophic

982 flagellates. Protist. 167, 411-424. https://doi.org/10.1016/j.protis.2016.07.001

983

Azovsky, A.I., Chertoprud, E.S., Garlitska, L.A., Mazei, Yu.A., Tikhonenkov, D.V., 2020.

984 Does size really matter in biogeography? Patterns and drivers of global distribution of marine

985 micro- and meiofauna. J. Biogeogr.47, 1180-1192. https://doi.org/10.1111/jbi.13771

986 Bass, D., Richards, T.A., Matthai, L., Marsh, V., Cavalier-Smith, T., 2007. DNA evidence

987 for global dispersal and probableendemicity of protozoa. BMC Evol. Biol. 7, 162-175.

988

https://doi.org/10.1186/1471-2148-7-162

989

Bass, D., Tikhonenkov, D.V., Foster, R., Dyal, P., Janouškovec, J., Keeling, P.J., Gardnera,

M., Neuhauserf, S., Hartikainena, H., Mylnikov, A.P., Berney, C., 2018. Rhizarian ‘novel clade

991

$10^{\prime}$ revealed as abundant and diverse planktonic and terrestrial flagellates, including Aquavolon $\mathrm{n}$.

992

gen. J. Eukaryot. Microbiol. 65(6), 828-842. https://doi.org/10.1111/jeu.12524

993

Bergesch, M., Odebrecht, C., Moestrup, O., 2008. Nanoflagellates from coastal waters of

994

Southern Brazil. Bot. Mar. 51, 35-50. https://doi.org/10.1515/BOT.2008.003

995

Brunet, T., Larson, B. T., Linden, T. A., Vermeij, M. J., McDonald, K., King, N., 2019.

996 Light-regulated collective contractility in a multicellular choanoflagellate. Science. 366(6463),

997 326-334. https://doi.org/10.1126/science.aay2346

998

Burki, F., Kaplan, M., Tikhonenkov, D.V., Zlatogursky, V., Minh, B.Q., Radaykina, L.V.,

999 Smirnov, A., Mylnikov, A.P., Keeling, P.J., 2016. Untangling the early diversification of

1000 eukaryotes: a phylogenomic study of the evolutionary origins of Centrohelida, Haptophyta and

1001 Cryptista. Proc. R. Soc. B: Biol. Sci. 283(1823),20152802. https://doi.org/10.1098/rspb.2015.2802

1002 Cann, J.P., Pennick, N.C., 1986. Observations on Petalomonas cantuscygni, n. sp., a new

1003 halo-tolerant strain. Arch. Protistenk. 132(1-2), 63-71. https://doi.org/10.1016/S0003-

1004

$9365(86) 80008-2$ 

perpetuity. It is made available under aCC-BY-ND 4.0 International license.

1006 (Protozoa: Apusozoa): new genera and species. Protist. 161(4), 549-576.

1007 https://doi.org/10.1016/j.protis.2010.04.002

1009 taxonomy of Centrohelid Heliozoan. Mol. Phylogenet. Evol. 44(3), 1186-1203.

1010 https://doi.org/10.1016/j.ympev.2007.04.019

1012 position of a novel marine sand-dwelling cercozoan: Clautriavia biflagellata $\mathrm{n}$. sp. Protist. 161(1),

Pinaciophora and Acanthocystis (Heliozoea, Sarcodina, Protozoa) from Ellis Fjord, Antarctica.

1020 diversity among unicellular Opisthokonts. Mol. Biol. Evol. 30, 802-805.

1021 https://doi.org/10.1093/molbev/mst006

Diversity and distribution of unicellular Opisthokonts along the European coast analyzed using 
1031 mixotrophy. FEMS Microbiol. Ecol. 46(3),317-329. https://doi.org/10.1016/S0168-

$1032 \quad 6496(03) 00248-4$

1033 Dürrschmidt, M., 1985. Electron microscopic observations on scales of species of the

1034 genus Acanthocystis (Centrohelidia, Heliozoa) from Chile. I. Arch. Protistenk. 129(1-4), 55-87.

1035 https://doi.org/10.1016/S0003-9365(85)80011-7

1036 Dürrschmidt, M., 1987a. An electron microscopical study of freshwater Heliozoa (genus

1037 Acanthocystis, Centrohelidia) from Chile, New Zealand, Malaysia and Sri Lanka. II. Arch.

1038 Protistenk. 133(1-2), 21-48. https://doi.org/10.1016/S0003-9365(87)80038-6

1039 Ekebom, J., Patterson, D.J., Vørs, N., 1995/6. Heterotrophic flagellates from coral reef

1040 sediments (Great Barier Reef, Australia). Arch. Protistenk. 146, 251-272.

1041 https://doi.org/10.1016/S0003-9365(96)80013-3

1042 Eglit, Y., Simpson, A.G.B., 2018. "Protist X" is a predatory anaerobe that represents a

1043 novel deep lineage of eukaryotes. Abstracts of the 5th Joint Meeting of PSA / ISOP, July 29-Aug.

1044 2, 2018, Vancouver, B.C. P. 91.

1045 Eglit, Y., Shiratori, T., Jerlstrom-Hultqvist, J., Roger, A.J., Ishida, K-I., Simpson, A.G.B.,

1046 2017. Meteora sporadica represents a new major lineage of eukaryotes. Book of Abstracts of $15^{\text {th }}$

1047 International Congress of Protistology, $30^{\text {th }}$ July $-4^{\text {th }}$ August 2017, Prague, Czech Republic. 2017.

$1048 \quad$ P. 71.

1049 Entz, G., 1883. Die Flagellaten der Kochsalzteiche zu Torda und Szamosfalva.

1050 Természetrajzi Fuzetek.7, 139-168.

1051 Ermolenko, E.A., Plotnikov, A.O., 2013. Ecology of Centrohelid Heliozoa in the Southern

1052 Urals reservoirs. Bull. Orenburg State Univ.10, 119-121. (in Russian with English summary).

1053 Fenchel, T., Finlay, B.J., 2004. The ubiquity of small species: patterns of local and global

1054 diversity. Bioscience. 54(8), 777-784. https://doi.org/10.1641/0006-

1055 

perpetuity. It is made available under aCC-BY-ND 4.0 International license.

Fenchel, T., Finlay, B.J., 2006. The diversity of microbes: resur-gence of the phenotype.

1057 Philos. Trans. R. Soc. B. 361, 1965-1973. https://doi.org/10.1098/rstb.2006.1924

1058

Finlay, B.J., Corliss, J.O., Esteban, G., Fenchel, T., 1996. Biodiversity at the microbial

1059

level: the number of free-living ciliates in the biosphere. Q. Rev. Biol. 71(2), 221-237.

1060

https://doi.org/10.1086/419370

1061

Foissner, W., 2004. Ubiquity and cosmopolitanism of protists questioned. SIL News. 43,

$10626-7$.

1063

Foissner, W., 2008. Protist diversity and distribution: some basic considerations. Biodivers.

1064

Conserv. 17, 235-242. https://doi.org/10.1007/s10531-007-9248-5

1065

Francé, R.H., 1897. Der Organismus der Craspedomonaden. Kiadja A. Kir. M.

1066 Természettudományi Társulat, Budapest.

1067 Gavelis, G.S., White, R.A., Suttle, C.A., Keeling, P.J., Leander, B.S., 2015. Single-cell

1068 transcriptomics using spliced leader PCR: Evidence for multiple losses of photosynthesis in

1069 polykrikoid dinoflagellates. BMC Genomics. 16(1), 528. https://doi.org/10.1186/s12864-015-

$1070 \quad 1636-8$

1071

Gawryluk, R.M., Tikhonenkov, D.V., Hehenberger, E., Husnik, F., Mylnikov, A.P.,

1072 Keeling, P.J., 2019. Non-photosynthetic predators are sister to red algae. Nature. 572(7768), 240-

1073 243. https://doi.org/10.1038/s41586-019-1398-6

1074 Geisen, S., Vaulot, D., Mahé, F., Lara, E., de Vargas, C., Bass, D., 2019. A user guide to

1075 environmental protistology: primers, metabarcoding, sequencing, and analyses.

1076 BioRxiv. 850610. https://doi.org/10.1101/850610

1077 Glücksman, E., Snell, E.A., Berney, C., Chao, E.E., Bass, D., Cavalier-Smith, T., 2011.

1078 The novel marine gliding zooflagellate genus Mantamonas (Mantamonadida ord.n.: Apusozoa).

1079 Protist. 162, 207-221. https://doi.org/10.1016/j.protis.2010.06.004 

perpetuity. It is made available under aCC-BY-ND 4.0 International license.

1081 diversity in "Spumella-like flagellates". J. Eukaryot. Microbiol. 63(4), 419-439.

1082 https://doi.org/10.1111/jeu.12287

1083 Guillou, L., Viprey, M., Chambouvet, A., Welsh, R.M., Kirkham, A.R., Massana, R.,

1084 Scanlan, D.J., Worden, A.Z., 2008. Widespread occurrence and genetic diversity of marine

1085 parasitoids belonging to Syndiniales (Alveolata). Environ. Microbiol. 10, 3349-3365.

1086 https://doi.org/10.1111/j.1462-2920.2008.01731.x

1087

Hammer, Ø., Harper, D.A.T., Ryan, P.D., 2001. PAST: Paleontological statistics software

1088 package for education and data analysis. Palaeontol. Electron. 4(1), 9.

1089 Hara, S., Chen, Y-L.L., Sheu, J-C., Takahashi, E., 1996. Choanoflagellates

1090 (Sarcomastigophora, Protozoa) from the Coastal Waters of Taiwan and Japan. I. Three new 1091 species. J. Eukaryot. Microbiol. 43(2), 136-143. https://doi.org/10.1111/j.15507408.1996.tb04494.x

1094 (Sarcomastigophora, Protozoa) from the coastal waters of Taiwan and Japan (II): Species

1095 composition and biogeography. Zool. Stud. 36(2), 98-110.

1096 Hehenberger, E., Tikhonenkov, D.V., Kolisko, M., del Campo, J., Esaulov, A.S.,

1097 Mylnikov, A.P., Keeling, P.J., 2017. Novel predators reshape holozoan phylogeny and reveal the

1098 presence of a two-component signaling system in the ancestor of animals. Curr. Biol. 27(13):

1099 2043-2050. https://doi.org/10.1016/j.cub.2017.06.006

1100 Howe, A.T., Bass, D., Scoble, J.M., Lewis, R., Vickerman, K., Arndt, H., Cavalier-Smith,

1101 T., 2011. Novel cultured protists identity deep-branching environmental DNA clades of Cercozoa:

1102 new genera Tremula, Micrometopion, Minimassisteria, Budifila, Peregrinia. Protist.162, 332-372.

1103 https://doi.org/10.1016/j.protis.2010.10.002 

perpetuity. It is made available under aCC-BY-ND 4.0 International license.

1105 2019. Phylogenomics supports the monophyly of the Cercozoa. Mol. Phylogenet. Evol. 130, 416-

1106 423. https://doi.org/10.1016/j.ympev.2018.09.004

1107 Janouškovec, J., Tikhonenkov, D., Mikhailov, K.V., Simdyanov, T.G., Aleoshin, V.V.,

1108 Mylnikov, A.P., Keeling P.J., 2013. Colponemids represent multiple ancient alveolate lineages.

1109 Curr. Biol. 25, 2546-2552. https://doi.org/10.1016/j.cub.2013.10.062

1110 Janouškovec, J., Tikhonenkov, D., Burki, F., Howe, A., Kolisko, M., Mylnikov, A.P.,

1111 Keeling, P.J., 2015. Factors mediating plastid dependency and the origins of parasitism in

1112 apicomplexans and their close relatives. Proc. Natl. Acad. Sci. USA. 112, 10200-10207.

1113 https://doi.org/10.1073/pnas.1423790112

1114 Janouškovec, J., Tikhonenkov, D., Burki, F., Howe, A.T., Rohwer, F.L., Mylnikov, A.P.,

1115 Keeling, P.J., 2017. A new lineage of eukaryotes illuminates early mitochondrial genome

1116 reduction. Curr. Biol. 27(23), 3717-3724. https://doi.org/10.1016/j.cub.2017.10.051

1117 Keeling, P.J., Campo, J.D., 2017. Marine protists are not just big bacteria. Curr. Biol. 27,

1118 R541-R549. https://doi.org/10.1016/j.cub.2017.03.075

1119 Kent, W.S., 1880. A manual of the Infusoria: including a description of all known

1120 Flagellate, Ciliate, and Tentaculiferous Protozoa, British and foreign, and an account of the

1121 organization and the affinities of the sponges. David Bogue, London.

1122 Kiss, A.K., Acs, E., Kiss, K.T., Török, J.K., 2009. Structure and seasonal dynamics of the

1123 protozoan community (heterotrophic flagellates, ciliates, amoeboid protozoa) in the plankton of a

1124 large river (River Danube, Hungary). Eur. J. Protistol. 45(2), 121-138.

1125 https://doi.org/10.1016/j.ejop.2008.08.002

1126 Koch, T.A., Ekelund, F., 2005. Strains of the heterotrophic flagellate Bodo designis from

1127 different environments vary considerably with respect to salinity preference and SSU rRNAgene

1128 composition. Protist. 156, 97-112. https://doi.org/10.1016/j.protis.2004.12.001 

perpetuity. It is made available under aCC-BY-ND 4.0 International license.

Kopylov, A.I., Ievleva, T.V., Kosolapova, N.G., 2015. Seasonal and annual variation of

1130 virioplankton abundance in rivers running through an industrial city (city of Cherepovets, Upper

1131 Volga). Inland Water Biol. 8(1), 38-46. https://doi.org/10.1134/S1995082914040075

1132 Kopylov, A.I., Mylnikov, A.P., Amgaabazar, E., 2006. Heterotrophic flagellates in rivers

1133 and lakes of Mongolia: species composition, abundance, biomass, and production. Biologia

1134 Vnutrennikh Vod. 1, 57-66. (in Russian with English summary)

1135 Ku, C., Sebé-Pedrós, A., 2019. Using single-cell transcriptomics to understand functional

1136 states and interactions in microbial eukaryotes. Philos. Trans. R. Soc. Lond., B, Biol. Sci.

1137 374(1786), 20190098. https://doi.org/10.1098/rstb.2019.0098

1138 Lara, E., Chatzinotas, A., Simpson, A.G., 2006. Andalucia (n. gen.)—-the deepest branch

1139 within jakobids (Jakobida; Excavata), based on morphological and molecular study of a new

1140 flagellate from soil. J. Eukaryot. Microbiol. 53(2), 112-120. https://doi.org/10.1111/j.1550-

$1141 \quad 7408.2005 .00081 . x$

1142 Larsen, J., Patterson, D.J., 1990. Some flagellates (Protista) from tropical marine

1143 sediments. J. Nat. Hist.24, 801-937. https://doi.org/10.1080/00222939000770571

1144 Lax, G., Eglit, Y., Eme, L., Bertrand, E.M., Roger, A.J., Simpson, A.G.B., 2018.

1145 Hemimastigophora is a novel supra-kingdom-level lineage of eukaryotes. Nature. 564, 410-414.

1146 https://doi.org/10.1038/s41586-018-0708-8

1147 Leadbeater, B.S.C., 1972. Fine structural observations on some marine Choanoflagellates

1148 from the coast of Norway. J. Mar. Biol. Ass. U.K. 52, 67-79.

1149 https://doi.org/10.1017/S0025315400018580

1150 Leadbeater, B.S.C., 1974. Ultrastructural observations on nanoplankton collected from the

1151 coast of Jugoslavia and the Bay of Algiers. J. Mar. Biol. Assoc. U.K. 54, 179-196.

1152 https://doi.org/10.1017/S0025315400022153 

perpetuity. It is made available under aCC-BY-ND 4.0 International license. as-sembly: the nudiform condition. II. Acanthoeca spectabilis Ellis. Protist. 159(3), 495-505. https://doi.org/10.1016/j.protis.2008.03.001

1157 choanoflagellates Acanthoeca spectabilis Ellis and A. brevipoda Ellis. Arch. Microbiol. 95(1), 

perpetuity. It is made available under aCC-BY-ND 4.0 International license.

1180 Single-cell transcriptomics of small microbial eukaryotes: limitations and potential. ISME J. 11(5),

1181 1282-1285. https://doi.org/10.1038/ismej.2016.190

1182 Lukas, I.A.N., 1967. Two new marine species of Paraphysomonas. J. Mar. Biol. Ass. U.K.

1183 47, 329-334. https://doi.org/10.1017/S0025315400056435

1184 Marchant, H.J., Perrin, R.A., 1990. Seasonal variation in abundance and species

1185 composition of Choanoflagellates (Acanthoecidae) at Antarctic coastal sites. Polar Biol. 10, 499-

1186 505. https://doi.org/10.1007/BF00233698

1187 Massana, R., Pedrós-Alió, C., 2008. Unveiling new microbial eukaryotes in the surface

1188 ocean. Curr. Opin. Microbiol. 11, 213-218. https://doi.org/10.1016/j.mib.2008.04.004

1189 Mazei, Yu.A., Tikhonenkov, D.V., 2006. Heterotrophic flagellates in the littoral and

1190 sublittoral zones of the southeast part of the Pechora Sea. Oceanology. 46(3), 368-375.

1191 https://doi.org/10.1134/S0001437006030088

1192 Mikrjukov, K.A., 2001. Heliozoa as a component of marine microbenthos: a study of

1193 heliozoa of the White sea. Ophelia. 54(1), 51-73.

1194 https://doi.org/10.1080/00785326.2001.10409455

1195 Mikrjukov, K.A., 1993. On the Centrohelid and Rotosphaerid Heliozoa from the environs

1196 of the Võrtsjärv limnological station in Estonia. Proc. Estonian Acad. Sci.42(2), 154-160.

1197 Mikrjukov, K.A., 1999. Interesting findings of heliozoan (Protista) in the Black Sea and

1198 Crimea: data on the similarity of sea and freshwater fauna of these organisms. Russ. J. Zool. 3(2),

1199 240-249. (in Russian with English summary)

1200 Mikrjukov, K.A., 2002. Centrohelid heliozoans (Centroheliozoa). KMK Sci. Press,

1201 Moscow. (in Russian)

1202 Moestrup, Ø., Thomsen, H.A., 1980. Preparations of shadow cast whole mounts. In:

1203 Handbook of Phycological Methods. Cambridge Univ. Press, Cambridge. 

perpetuity. It is made available under aCC-BY-ND 4.0 International license.

Mylnikov, A.P., 1999. New brackish water amoeboid flagellates of the genus

1205 Amastigomonas (Apusomonadida, Protozoa). Zool Zhurn. 78, 771-777. (in Russian with English

1206 summary)

1207 Mylnikov, A.P., Karpov, S.A., 1993. A new representative of colourless flagellates

1208 Thaumatomonas seravini sp. n. (Thaumatomonadida, Protista). Zool. Zhurn. 72(3), 5-9. (in

1209 Russian with English summary)

1210 Mylnikov, A.P., Kosolapova, N.G., Mylnikov, A.A., 2002. Planktonic heterotrophic

1211 flagellates of small water bodies in Yaroslavl oblast. Zool. Zhurn. 81(2), 131-140. (in Russian

1212 with English summary)

1213 Mylnikov, A.P., Tikhonenkov, D.V., Karpov, S.A., Wylezich, C., 2019. Microscopical

1214 atudies on Ministeria vibrans Tong, 1997 (Filasterea) highlight the cytoskeletal structure of the

1215 common ancestor of Filasterea, Metazoa and Choanoflagellata. Protist. 170(4), 385-396.

1216 https://doi.org/10.1016/j.protis.2019.07.001

1217 Mylnikov, A.P., Tikhonenkov, D.V., Simdyanov, T.G., 2006. The fauna and morphology

1218 of heterotrophic flagellates from the Vorontsovskaya cave (Krasnodar Krai). Zool. Zhurn. 85(10),

1219 1164-1175. (in Russian with English summary)

1220 Nicholls, K.H., 1981. Six Chrysophyceae new to North America. Phycologia. 20(2), 131-

1221 137. https://doi.org/10.2216/i0031-8884-20-2-131.1

1222 Nicholls, K.H., 2013. New and little-known marine and freshwater species of the silica-

1223 scaled genera Thaumatomastix and Reckertia (Cercozoa: Thaumatomonadida). J. Mar. Biol.

1224 Ass.U.K.93(5), 1231-1244. https://doi.org/10.1017/S0025315412001373

1225 Nitsche, F., Arndt, H., 2015. Comparison of similar Arctic and Antarctic morphotypes of

1226 heterotrophic protists regarding their genotypes and ecotypes. Protist. 166, 42-57.

1227 https://doi.org/10.1016/j.protis.2014.11.002 

perpetuity. It is made available under aCC-BY-ND 4.0 International license.

Norris, R.E., 1965. Neustonic marine Craspedomonadales (Choanoflagellates) from

1229 Washington and California. J. Protozool. 12,589-602. https://doi.org/10.1111/j.1550-

$1230 \quad 7408.1965 . t b 03260 . x$

1231 Okamoto, N., Gawryluk, R.M.R., del Campo, J., Strassert, J.F.H., Lukeš, L., Richards,

1232 T.A., Worden, A.Z., Santoro, A.E., Keeling P.J., 2019. A revised taxonomy of Diplonemids

1233 including the Eupelagonemidae n. fam. and a type species, Eupelagonema oceanic n. gen. \& sp. J.

1234 Eukaryot. Microbiol. 66, 519-524. https://doi.org/10.1111/jeu.12679

1235

O’Kelly, C.J. Nerad, T.A., 1999. Malawimonas jakobiformis n. gen., n. sp.

1236 (Malawimonadidae n. fam.): A Jakoba-like heterotrophic nanoflagellate with discoidal

1237 mitochondrial cristae. J. Eukaryot. Microbiol. 46, 522-531. https://doi.org/10.1111/j.1550-

$1238 \quad 7408.1999 . t b 06070 . x$

1239 Onsbring, H., Tice, A.K., Barton, B.T., Brown, M.W., Ettema, T.J.G., 2019. An efficient

1240 single-cell transcriptomics workflow to assess protist diversity and lifestyle. bioRxiv, 782235.

1241 https://doi.org/10.1101/782235

1242 Park, J.S., Cho, B.C., Simpson, A.G.B., 2006. Halocafeteria seosinensis gen. et sp. nov.

1243 (Bicosoecida), a halophilic bacterivorous nanoflagellate isolated from a solar saltern.

1244 Extremophiles. 10(6), 493-504. https://doi.org/10.1007/s00792-006-0001-x

1245 Patterson, D.J., Larsen, J., 1991. Biology of free-living heterotrophic flagellates. University

1246 Press, Oxford.

1247 Patterson, D.J., Nygaard, K., Steinberg, G., Turley, C.M., 1993. Heterotrophic flagellates

1248 and other protists associated with oceanic detritus throughout the water column in the mid North

1249 Atlantic. J. Mar. Biol. Ass. U.K. 73(1), 67-95. https://doi.org/10.1017/S0025315400032653

1250 Patterson, D.J., Simpson, A.G.B., 1996. Heterotrophic flagellates from coastal marine and

1251 hypersaline sediments in Western Australia. Eur. J. Protistol. 32, 423-

1252 448.https://doi.org/10.1016/S0932-4739(96)80003-4 

perpetuity. It is made available under aCC-BY-ND 4.0 International license.

Pawlowski, J., Lejzerowicz, F., Apotheloz-Perret-Gentil, L., Visco, J., Esling, P., 2016.

1254 Protist metabarcoding and environmental biomonitoring: Time for change. Eur J Protistol. 55(Pt

1255 A), 12-25. https://doi:10.1016/j.ejop.2016.02.003

1256

Pfandl, K., Chatzinotas, A., Dyal, P., Boenigk, J., 2009. SSU rRNA gene variation resolves

1257 population heterogeneity and ecophysiological differentiation within a morphospecies

1258 (Stramenopiles, Chrysophyceae). Limnol. Oceanogr. 54, 171-181.

1259 https://doi.org/10.4319/lo.2009.54.1.0171

1260 Plotnikov, A.O., Selivanova, E.A., Nemtseva, N.V., 2011. Species diversity of

1261 heterotrophic flagellates in saline Salt-Iletsk' Lakes. Izv. Penz. Gos. Pedagog. Univ. im. V.G.

1262 Belinskogo. 25,548-557. (in Russian with English summary)

1263 Porter, D., 1973. Isonema papillatum sp. n., a new colorless marine flagellate: a light and

1264 electronmicroscopic study. J. Eukaryot. Microbiol. 20(3), 351-356. https://doi.org/10.1111/j.1550-

1265 7408.1973.tb00895.x

1266

Prokina, K.I., 2020. Heterotrophic flagellates from the saline lakes of the Crimean

1267 Peninsula. Ecosystem Transformation. 3(2), 1-8. https://doi.org/10.23859/estr-200329. (in Russian

1268 with English summary)

1269 Prokina, K.I., Mylnikov, A.P., 2018.Heterotrophic flagellates from freshwater and marine

1270 habitats of South Patagonia and Tierra del Fuego, Chile. Zool. Zhurn. 97(12), 1439-1460.

1271 https://doi.org/10.1134/S0044513418120097 (in Russian with English summary)

Prokina, K.I., Mylnikov, A.P., 2019. Centrohelid Heliozoans from freshwater habitats of

1273 different types of South Patagonia and Tierra del Fuego, Chile. Inland Water Biol.12(1), 10-20.

1274 https://doi.org/10.1134/S1995082919010164

1275 Prokina, K.I., Mylnikov, A.P., Galanina, O.V., Philippov, D.A., 2017. First report on

1276 heterotrophic flagellates in the mires of Arkhangelsk region, Russia. Biol. Bull. 44(9), 1067-1078.

1277 https://doi.org/10.1134/S1062359017090096. (in Russian with English summary) 

perpetuity. It is made available under aCC-BY-ND 4.0 International license.

1279 (Centroplasthelida Febvre-Chevalier et Febvre 1984) from Vietnam. Zool. Zhurn. 98(9), 965-977.

1280 https://doi.org/10.1134/S0044513419090095. (in Russian with English summary)

1281 Prokina, K.I., Turbanov, I.S., Tikhonenkov, D.V., Mylnikov, A.P., 2018. Free-living

1282 heterotrophic flagellates from bays of Sevastopol (the Black Sea littoral). Protistology. 12(4), 2021283 222. https://doi.org/10.21685/1680-0826-2018-12-4-5

1284 Roy, J., Faktorova, D., Benada, O., Lukeš, J., Burger, G., 2007. Description of

1285 Rhynchopuseuleeides n. sp. (Diplonemea), a free-living marine Euglenozoan. J. Eukaryot.

1286 Microbiol. 54(2), 137-145. https://doi.org/10.1111/j.1550-7408.2007.00244.x

1287 Ruinen, J., 1938. Notizen über Salzflagellaten II. Über die Verbreitung der Salzflagellaten.

1288 Arch. Protistenkd.90, 210-258.

1289 Schnepf, E., 1994. Light and electron microscopical observations in

1290 Rhynchopuscoscinodiscivorus spec. nov., a colorless, phagotrophic Euglenozoan with concealed

1291 flagella. Arch. Protistenkd.144, 63-74. https://doi.org/10.1016/S0003-9365(11)80225-3

1292 Schoenle, A., Hohlfeld, M., Rosse, M., Filz, P., Wylezich, C., Nitsche, F., Arndt, H., 2020.

1293 Global comparison of bicosoecid Cafeteria-like flagellates from the deep ocean and surface

1294 waters, with reorganization of the family Cafeteriaceae. Eur. J. Protistol. 73, 125665.

1295 https://doi.org/10.1016/j.ejop.2019.125665

Scheckenbach, F., Wylezich, C., Mylnikov, A.P., Weitere, M., Arndt, H., 2006. Molecular

1297 comparisons of freshwater and marine isolates of the same morphospecies of heterotrophic

1298 flagellates. Appl. Environ. Microbiol. 72, 6638-6643. https://doi.org/10.1128/AEM.02547-05

1299 Scoble, J.M., Cavalier-Smith, T., 2014a. Scale evolution in Paraphysomonadida

1300 (Chrysophyceae): sequence phylogeny and revised taxonomy of Paraphysomonas, new genus

1301 Clathromonas, and 25 new species. Eur. J. Protistol. 50, 551-592.

1302 https://doi.org/10.1016/j.ejop.2014.08.001 

perpetuity. It is made available under aCC-BY-ND 4.0 International license.

Scoble, J.M., Cavalier-Smith, T., 2014b. Scale evolution, sequence phylogeny, and

1304 taxonomy of thaumatomonad Cercozoa: 11 new species and new genera Scutellomonas,

1305 Cowlomonas, Thaumatospina and Ovaloplaca. Eur. J. Protistol. 50, 270-313.

1306 https://doi.org/10.1016/j.ejop.2013.12.005

1307 Shatilovich, A.V., Mylnikov, A.P., Stoopin, D.V., 2010. The fauna and morphology of

1308 heterotrophic flagellates and heliozoans from late pleistocene fossil rodent burrows (Kolyma

1309 lowland). Zool. Zhurn. 89(4), 387-397. (in Russian with English summary)

1310 Skuja, H., 1948. Taxonomie des Phytoplanktons einiger Seen in Uppland, Schweden.

1311 Symb. Bot. Ups.9, 1-399.

1312 Smith, P.J., Hobson, L.A., 1994. Temporal variations in the taxonomic composition of

1313 flagellated nanoplankton in a temperate fjord 1. J. Phycol.30(3), 369-375.

1314 https://doi.org/10.1111/j.0022-3646.1994.00369.x

1315 Starmach, K., 1968. Flora slodkowodna polski. Tom 5. Chrysophyta I. Chrysophyceae -

1316 zlotowiciowce oraz wiciowce bezbarwne - zooflagellata wolnozyjace. Panstwowe Wydawnictwo

1317 Naukowe, Warszawa.

1318 Stoupin, D., Kiss, A.K., Arndt, H., Shatilovich, A.V., Gilichinsky, D.A., Nitsche, F., 2012.

1319 Cryptic diversity within the choanoflagellate morphospecies complex Codosiga botrytis -

1320 Phylogeny and morphology of ancient and modern isolates. Eur. J. Protistol. 48, 263-273.

1321 https://doi.org/10.1016/j.ejop.2012.01.004

1322 Strassert, J.F., Tikhonenkov, D.V., Pombert, J.F., Kolisko, M., Tai, V., Mylnikov, A.P.,

1323 Keeling, P.J., 2016. Moramonas marocensis gen. nov., sp. nov.: a jakobid flagellate isolated from

1324 desert soil with a bacteria-like, but bloated mitochondrial genome. Open biol. 6(2), 150239.

1325 https://doi.org/10.1098/rsob.150239

1327 Phylogenomic Analysis of the Enigmatic Phylum Telonemia Further Resolves the Eukaryote Tree 1328 of Life. Mol. Biol. Evol. 36, 757-765. https://doi.org/10.1093/molbev/msz012 

perpetuity. It is made available under aCC-BY-ND 4.0 International license.

1330 cycle, ultrastructure, and phylogeny of new Diplonemids and their endosymbiotic bacteria. Am.

1331 Soc. Microbiol. 9(2), e02447-17. https://doi.org/10.1128/mBio.02447-17

1332 Thomsen, H.A., 1973. Studies on marine Choanoflagellates I. Silicified Choanoflagellates

1333 of the Isefjord (Denmark). Ophelia. 12(1-2), 1-26.

1334 https://doi.org/10.1080/00785326.1973.10430116

1335 Thomsen, H.A., Østergaard, J.B., 2019. Loricate choanoflagellates (Acanthoecida) from

1336 warm water seas. III. Acanthocorbis Hara and Takahashi and Stephanoeca Ellis. Eur. J. Protistol.

1337 69, 52-69. https://doi.org/10.1016/j.ejop.2019.02.001

1338 Throndsen, J., Zingone, A., 1994. Micronomads of the Mediterranean Sea. Giornale

1339 Botanico Italiano: Official J. Bot. Italiana.128 (6),1029-1106.

1340 https://doi.org/10.1080/11263509409436468

1341 Tikhonenkov, D.V., 2006. Fauna, morphology and community structure of free-living

1342 heterotrophic flagellates from different type of freshwater and marine biotopes. $\mathrm{PhD}$ thesis. (in

1343 Russian)

1344 Tikhonenkov, D.V., 2009. Benthic heterotrophic flagellates from the Red Sea littoral (the

1345 gulf of Suez, Egypt). Zool. Zhurn. 88(9), 1-7. (in Russian with English summary)

1346 Tikhonenkov, D.V., Mazei, Yu.A., 2007. Species composition and distribution of

1347 heterotrophic flagellates in the Middle-Volga wetlands. Povolzhskii ekologicheskii zhurnal. 3,

1348 227-234. (in Russian with English summary)

1349 Tikhonenkov, D.V., Mazei, Yu.A., 2013. Distribution of benthic heterotrophic flagellates

1350 along salinity gradient: correlation between active and cryptic species diversity in the White Sea 1351 estuary. Uspekhi sovremennoi biologii. 133(2). 178-190. (in Russian with English summary)

1352 Tikhonenkov, D.V., Mazei. Yu.A., Mylnikov, A.P., 2006. Species diversity of

1353 heterotrophic flagellates in the White Sea littoral sites. Eur. J. Protistol.42, 191-200.

1354 https://doi.org/10.1016/j.ejop.2006.05.001 

perpetuity. It is made available under aCC-BY-ND 4.0 International license.

Tikhonenkov, D.V., Mazei, Y.A., Embulaeva, E.A., 2008. Degradational succession of a

1356 community of heterotrophic flagellates in microcosm experiments. Zh. Obshch. Biol. 69, 57-64.

1357 (in Russian with English summary)

1358 Tikhonenkov, D.V., Mazei, Yu.A., Mylnikov, A.P., Kireev, A.V., 2008. On the

1359 morphological variability of loricate heterotrophic flagellates (Protista). Izv. Penz. gos. pedagog.

1360 univ. im.i V. G. Belinskogo. 10(14), 72-77. (in Russian with English summary)

1361 Tikhonenkov, D.V., Mylnikov, A.P., Gong, Y.C., Feng, W.S., Mazei, Yu., 2012.

1362 Heterotrophic flagellates from freshwater and soil habitats in subtropical China (Wuhan Area,

1363 Hubei Province). Acta Protozool. 51, 63-77. https://doi.org/10.4467/16890027AP.12.006.0389

1364 Tikhonenkov, D.V., Janouškovec, J., Mylnikov, A.P., Mikhailov, K.V., Simdyanov, T.G.,

1365 Aleoshin V.V., Keeling P.J., 2014. Description of Colponema vietnamica sp. n. and Acavomonas

1366 peruviana n. gen. n. sp., two new alveolate phyla (Colponemidia nom. nov. and Acavomonidia

1367 nom. nov.) and their contributions to reconstructing the ancestral state of alveolates and

1368 eukaryotes. PloS ONE. 9, e95467. https://doi.org/10.1371/journal.pone.0095467

1369 Tikhonenkov, D.V., Hehenberger, E., Esaulov, A.S., Belyakova, O.I., Mazei, Yu.A.,

1370 Mylnikov, A.P., Keeling, P.J., 2020a. Insights into the origin of metazoan multicellularity from

1371 predatory unicellular relatives of animals. BMC Biology. 18, 39. https://doi.org/10.1186/s12915-

$1372 \quad 020-0762-1$

1373 Tikhonenkov, D.V., Strassert, J.F.S., Janouškovec, J., Mylnikov, A.P., Aleoshin, V.V.,

1374 Burki, F., Keeling, P.J., 2020b. Predatory colponemids are the sister group to all other alveolates.

1375 Mol. Phyl. Evol. 149, 106839. https://doi.org/10.1016/j.ympev.2020.106839

1376 Tong, S.M., 1994. Heterotrophic flagellates in Southampton water. PhD thesis.

1377 Tong, S.M., 1997a. Choanoflagellates in Southampton water, including the description of

1378 three new species. J. Mar. Biol. Ass. U.K. 77(4), 929-958.

1379 https://doi.org/10.1017/S0025315400038546 
Tong, S.M., 1997b. Heterotrophic flagellates and other protists from Southampton water,

1381 UK. Ophelia. 47(2), 71-131. https://doi.org/10.1080/00785236.1997.10427291

Tong, S.M., 1997c. Heterotrophic flagellates from the water column in Shark bay, Western

1383 Australia. Mar. Biol. 128, 517-536. https://doi.org/10.1007/s002270050118

1384 Tong, S.M., Nygaard, K., Bernard, C., Vørs, N., Patterson, D.J., 1998. Heterotrophic

1385 flagellates from the water column in Port Jackson, Sydney, Australia. Eur. J. Protistol. 34, 162-

1386 194. https://doi.org/10.1016/S0932-4739(98)80027-8

1387 de Vargas, C., Audic, S., Henry, N., Decelle, J., Mahe, F. Logares, R., Lara, E., Berney, C.,

13881 Le Bescot, N., Probert, I., Carmichael, M., Poulain, J., Romac, S., Colin, S., Aury, J.-M., Bittner,

1389 L., Chaffron, S., Dunthorn, M., Engelen, S., Flegontova, O., Guidi, L., Horák, A., Jaillon, O.,

1390 Lima-Mendez, G., Lukeš, J., Malviya, Sh., Morard, R., Mulot, M., Scalco, E., Siano, R., Vincent,

1391 F., Zingone, A., Dimier, C., Picheral, M., Searson, S., Kandels-Lewis, S., Tara Oceans

1392 Coordinators, G. Acinas, S.G., Bork, P., Bowler, Ch., Gorsky, G., Grimsley, N., Hingamp, P.,

1393 Iudicone, D., Not, F., Ogata, H., Pesant, S., Raes, J., Sieracki, M.E., Speich, S., Stemmann, L.,

1394 Sunagawa, Sh., Weissenbach, J., Wincker, P., Karsenti, E., 2015. Eukaryotic plankton diversity in

1395 the sunlit ocean. Science. 348, 1261605-1261605. https://doi.org/10.1126/science.1261605

1396 Vørs, N., 1992. Heterotrophic amoebae, flagellates and heliozoan from the Tvärminne area,

1397 gulf of Finland, in 1988 - 1990. Ophelia. 36(1), 1-109.

1398 https://doi.org/10.1080/00785326.1992.10429930

1399 Vørs, N., 1993. Heterotrophic amoebae, flagellates and heliozoan from Arctic marine

1400 waters (North West Territories, Canada and West Greenland). Polar Biol. 13, 113-126.

1401 https://doi.org/10.1007/BF00238544

1402 Yabuki, A., Gyaltshen, Y., Heiss, A.A., Fujikura, K., Kim, E., 2018. Ophirina amphinema

1403 n. gen., n. sp., a new deeply branching discobid with phylogenetic affinity to Jakobids. Sci. Rep.

1404 8(1), 1-14. https://doi.org/10.1038/s41598-018-34504-6 

perpetuity. It is made available under aCC-BY-ND 4.0 International license.

Yubuki, N., Pánek, T., Yabuki, A., Čepička, I., Takishita, K., Inagaki, Yu., Leander, B.S.,

1406 2015. Morphological identities of two different marine stramenopile environmental sequence

1407 clades: Bicosoeca kenaiensis (Hilliard, 1971) and Cantina marsupialis (Larsen and Patterson,

1408 1990) gen. nov., comb. nov. J. Eukaryot. Microbiol. 62, 532-542.

1409 https://doi.org/10.1111/jeu.12207

1410 Zhukov, B.F., Karpov, S.A., 1985. Freshwater choanoflagellates. Nauka, Leningrad. (in

1411 Russian).

1412 Zlatogursky, V.V., 2016. There and back again: parallel evolution of cell coverings in

1413 centrohelid heliozoans. Protist. 167(1), 51-66. https://doi.org/10.1016/j.protis.2015.12.002

1414 Zlatogursky, V.V., Drachko, D., Klimov, V.I., Shishkin, Y., 2018. On the phylogenetic

1415 position of the genus Raphidocystis (Haptista: Centroplasthelida) with notes on the dimorphism in

1416 centrohelid life cycle. Eur. J. Protistol.64, 82-90. https://doi.org/10.1016/j.ejop.2018.03.006 
1419 Table. Characteristics of sampling points

\begin{tabular}{|c|c|c|c|c|c|}
\hline Habitat & $\begin{array}{c}\text { Coordinates, } \mathrm{N}, \\
\mathrm{W}\end{array}$ & Date & Biotope & Salinity, \%o & Depth, m \\
\hline \multirow{2}{*}{$\begin{array}{l}\text { 1. Turtle lagoon BokaAs- } \\
\text { cension }\end{array}$} & \multirow{2}{*}{$\begin{array}{l}12^{\circ} 16^{\prime} 22.0^{\prime \prime} \\
69^{\circ} 03^{\prime} 14.0^{\prime \prime}\end{array}$} & \multirow{2}{*}{$\begin{array}{l}\text { April 20, } \\
2018\end{array}$} & $\begin{array}{l}\text { 1a. Interstitial } \\
\text { sand water }\end{array}$ & \multirow[t]{2}{*}{35} & \multirow[t]{2}{*}{0} \\
\hline & & & 1b. Sand & & \\
\hline \multirow{5}{*}{$\begin{array}{l}\text { 2. The eastern point of } \\
\text { the Curacao island }\end{array}$} & \multirow{5}{*}{$\begin{array}{l}12^{\circ} 12^{\prime} 32.3^{\prime \prime} \\
68^{\circ} 48^{\prime} 58.8^{\prime \prime}\end{array}$} & \multirow{5}{*}{$\begin{array}{l}\text { April 24, } \\
2018\end{array}$} & 2a. Sponge & \multirow{5}{*}{35} & \multirow{5}{*}{24.7} \\
\hline & & & 2b. Coral & & \\
\hline & & & 2c. Coral sand & & \\
\hline & & & 2d. Sand & & \\
\hline & & & $\begin{array}{l}\text { 2e. Sargassum } \\
\text { algae wrings }\end{array}$ & & \\
\hline \multirow{4}{*}{ 3. Bay SantaMartha } & \multirow{4}{*}{$\begin{array}{l}12^{\circ} 16^{\prime} 05.1^{\prime \prime} \\
69^{\circ} 07^{\prime} 43.7^{\prime \prime}\end{array}$} & \multirow{4}{*}{$\begin{array}{l}\text { April 26, } \\
2018\end{array}$} & 3a. Sponge & \multirow{3}{*}{35} & \multirow{3}{*}{20} \\
\hline & & & 3b. Coral & & \\
\hline & & & 3c. Sand & & \\
\hline & & & 3d. Coral sand & 35 & 0 \\
\hline \multirow{4}{*}{$\begin{array}{l}\text { 4. "Water Factory" } \\
\text { sampling site near water } \\
\text { treatment plant }\end{array}$} & \multirow{4}{*}{$\begin{array}{l}12^{\circ} 06^{\prime} 34.0^{\prime \prime} \\
68^{\circ} 57^{\prime} 14.9^{\prime \prime}\end{array}$} & \multirow{4}{*}{$\begin{array}{l}\text { April 19, } \\
2018\end{array}$} & 4a. Sponge & \multirow{4}{*}{35} & \multirow{4}{*}{$12-18$} \\
\hline & & & 4b. Coral & & \\
\hline & & & 4c. Sand & & \\
\hline & & & $\begin{array}{l}\text { 4d. Water } \\
\text { column }\end{array}$ & & \\
\hline \multirow{3}{*}{$\begin{array}{l}\text { 5. The western point of } \\
\text { the Curacao island }\end{array}$} & \multirow{3}{*}{$\begin{array}{l}12^{\circ} 22^{\prime} 31.7^{\prime \prime} \\
69^{\circ} 09^{\prime} 29.7^{\prime \prime}\end{array}$} & \multirow{3}{*}{$\begin{array}{l}\text { April 26, } \\
2018\end{array}$} & 5a. Sponge & \multirow{3}{*}{35} & \multirow{3}{*}{20} \\
\hline & & & 5b. Coral & & \\
\hline & & & 5c. Sand & & \\
\hline $\begin{array}{l}\text { 6. Reef near the Carmabi } \\
\text { research station }\end{array}$ & $12^{\circ} 07^{\prime} 19.8^{\prime \prime}$ & $\begin{array}{l}\text { April 22, } \\
2018\end{array}$ & 6. Coral & 35 & 20 \\
\hline \multirow{2}{*}{ 7. Hilton Hotel Beach } & $\frac{68^{5} 5809.4^{\prime \prime}}{12^{\circ} 07^{\prime} 17.3^{\prime \prime}}$ & \multirow{2}{*}{$\begin{array}{l}\text { April 24, } \\
2018 \\
\end{array}$} & & \multirow[b]{2}{*}{35} & \multirow[b]{2}{*}{0} \\
\hline & $68^{\circ} 58^{\prime} 08.8^{\prime \prime}$ & & 7. Coral sand & & \\
\hline \multirow{2}{*}{$\begin{array}{l}\text { 8. Hypersaline lagoon } \\
\text { Saliña Sint Maria }\end{array}$} & & & 8a. Black clay & & \\
\hline & $69^{\circ} 03^{\prime} 15.3^{\prime \prime}$ & $\begin{array}{l}\text { April 20, } \\
2018\end{array}$ & 8b. Water & 52 & 0 \\
\hline
\end{tabular}


1421 Figure legends

Fig. 1. Morphology of observed heterotrophic flagellates (a-k-DIC, $1-n-T E M)$ : $a-c-$

1423 Thecamonas sp.; $\mathrm{d}-\mathrm{g}$ - Ministeria vibrans (d, e - non-moving cell, $\mathrm{f}-\mathrm{g}$ - moving cell); $\mathrm{h}-\mathrm{j}-$

1424 Salpingoeca pyxidium; $\mathrm{k}-\mathrm{n}$ - Acanthoeca spectabilis ( $\mathrm{k}$ - living cell, 1 - whole lorica; $\mathrm{m}$ -

1425 posterior chamber of the lorica; $\mathrm{n}$ - anterior chamber of the lorica). Abbreviations: acr - acronema;

1426 a.f - anterior flagellum; cl - collar; c.st - costal strips; fl - flagellum; gr - granules; lr - lorica; $1 . c$

1427 - longitudinal costa; mv - microvilli; p.f - posterior flagellum; ps - pseudopodia; sl - sleeve; st 1428 stalk. Scale bars: $5 \mu \mathrm{m}$.

1429 Fig. 2. Morphology of observed heterotrophic flagellates (a, b-PhC, c-e, h- TEM, f, g-

1430 SEM, i-m - DIC): a-d - Acanthocorbis camarensis (a, b - living cell, c, d - loricae); e- $\mathrm{h}-$

1431 Stephanoeca supracostata (e, $\mathrm{f}$ - whole lorica, $\mathrm{g}$ - posterior chamber, $\mathrm{h}$ - mouth of the lorica); $\mathrm{i}, \mathrm{j}$

1432 - Cyranomonas australis ( $\mathrm{i}$ - flagella in focus, $\mathrm{j}$ - attached particles in focus); $\mathrm{k}-\mathrm{m}$ - Clautriavia

1433 biflagellatta. Abbreviations: acr - acronema; a.f - anterior flagellum; c.st - costae strips; l.f - long

1434 flagellum; sh.f - short flagellum; t.c - transversal costa; v.d - ventral depression. Scale bars: a-f,

$1435 \mathrm{i}-\mathrm{m}-5 \mu \mathrm{m} ; \mathrm{g}, \mathrm{h}-2 \mu \mathrm{m}$.

1436 Fig. 3. Morphology of observed heterotrophic flagellates (TEM): a-c-Thaumatomonas

1437 seravini; $\mathrm{d}-\mathrm{f}-$ Paraphysomonas foraminifera; $\mathrm{g}-\mathrm{i}$ - Paraphysomonas $\mathrm{sp}$. Abbreviations: bs - base

1438 of spine scale; fl - flagellum; m.a - middle annulus; sc - scales; sh - shaft; pr - perforations. Scale

1439 bars: a, g-5 $4 \mathrm{~m}$; b, c, d-f, h, I - $1 \mu \mathrm{m}$.

1440 Fig. 4. Morphology of observed scales of centrohelid heliozoans (a-c - SEM; $d-j-$ TEM):

1441 a-c - Raphydocystis bruni (a, b - scale aggregation of whole cell; $\mathrm{c}-$ single scale); $\mathrm{d}-\mathrm{g}-$

1442 Choanocystis perpusilla (d, e - scale aggregation of whole cell; $\mathrm{f}$ - spine scale; $\mathrm{g}$ - plate scales);

$1443 \mathrm{~h}-\mathrm{j}$ - Heterophrys-like organism. Abbreviations: a.r - axial ridge; ax - axopodia; bs - base of

1444 scale; fr - furcae; m.r - marginal rim; $\mathrm{pl}$ - poles of scales; sh - shaft; sp - spicules. Scale bars: a,

$1445 \mathrm{~d}, \mathrm{~h}-5 \mu \mathrm{m} ; \mathrm{b}, \mathrm{c}, \mathrm{e}-\mathrm{g}, \mathrm{I}, \mathrm{j}-1 \mu \mathrm{m}$. 

perpetuity. It is made available under aCC-BY-ND 4.0 International license.

Fig. 5. Morphology of observed heterotrophic flagellates (DIC): a-c-Petalomonas

cantuscygni; $\mathrm{d}-\mathrm{f}-$ Ploeotia adhaerens; $\mathrm{g}-\mathrm{i}-P$. robusta; $\mathrm{i}-\mathrm{m}$-Diplonema ambulator; $\mathrm{n}, \mathrm{o}-$

1449 Rhynchopus amitus. Abbreviations: a.f - anterior flagellum; a.pr - apical protrusion (papilla); a.sl

1450 - anterior sleeve; fl - flagellum; f.p - flagellar pocket; f.v - food vacuole; grv - grooves; i.o -

1451 ingestion organelle; $1 . s$ - lip-like structure; p.f - posterior flagellum; p.sl - posterior sleeve; v.g -

1452 ventral groove; o.f.p - openings of flagellar pocket; $r g$ - ridges. Scale bars: $a-c, j-o-5 \mu m ; d-i-$

$145310 \mu \mathrm{m}$.

Fig. 5. Morphology of observed heterotrophic flagellates (DIC): a-c-Mantamonas

plastica; d, e - "Heterochromonas opaca"; f-i - "Protist 1"; (f - both flagella in focus; $\mathrm{g}, \mathrm{h}$ - cell

turns; $\mathrm{i}, \mathrm{j}$ - cell and anterior flagellum in focus $) ; \mathrm{k}-\mathrm{p}$ - "Protist 2" $(\mathrm{k}-\mathrm{n}-$ view from lateral side; $\mathrm{o}$, $\mathrm{p}$ - view from ventral side, with ventral groove). Abbreviations: a.f - anterior flagellum; a.pr apical protrusion; fl - flagellum; p.f - posterior flagellum; ps - pseudopodia; v.d - ventral depression; v.g - ventral groove. Scale bars: $5 \mu \mathrm{m}$.

1461 "Protist 4" (f - non-swimming cell; $\mathrm{g}-\mathrm{j}$ - swimming cells); $\mathrm{k}-\mathrm{q}$ "Protist 5" (1, p - narrow starved

1462 cells; $\mathrm{k}, \mathrm{m}, \mathrm{n}$ - saturated cells with prominent food vacuoles; $\mathrm{n}-\mathrm{q}$ - ventral groove (depression)).

1463 Abbreviations: acr - acronema; a.f - anterior flagellum; f.v - food vacuole; p.f - posterior

1464 flagellum; p.t - protoplasmic tail; tb - tubercles; v.g - ventral groove; v.p - ventral protrusion.

1465 Scale bar: $5 \mu \mathrm{m}$.

1467 composition of heterotrophic flagellates.

$1468 \quad$ Fig. 9. Species accumulation curve. 
bioRxiv preprint doi: https://doi.org/10.1101/2020.08.10.243865; this version posted August 10, 2020. The copyright holder for this preprint (which was not certified by peer review) is the author/funder, who has granted bioRxiv a license to display the preprint in perpetuity. It is made available under aCC-BY-ND 4.0 International license.

\section{Figure 1}
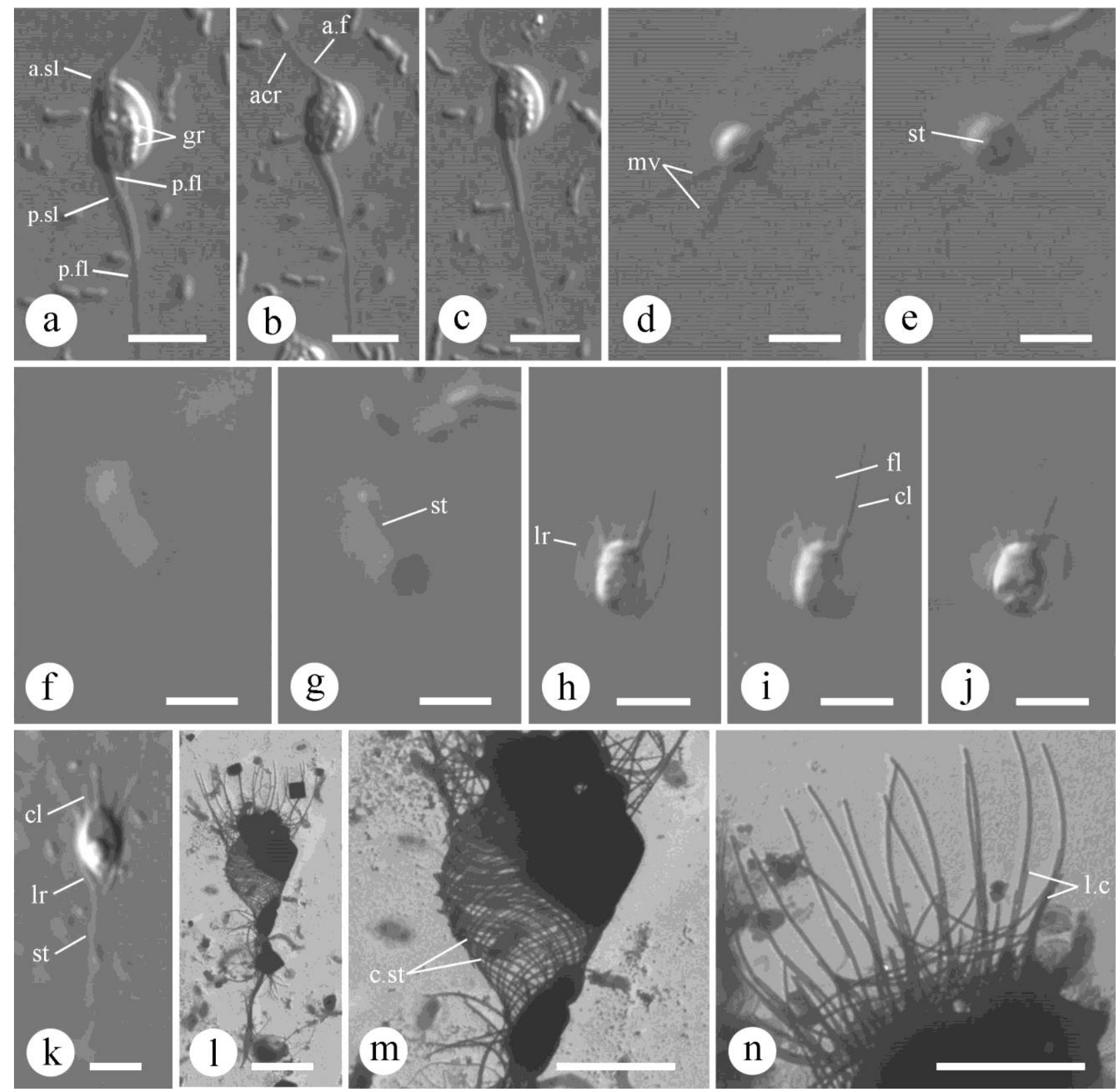

1473

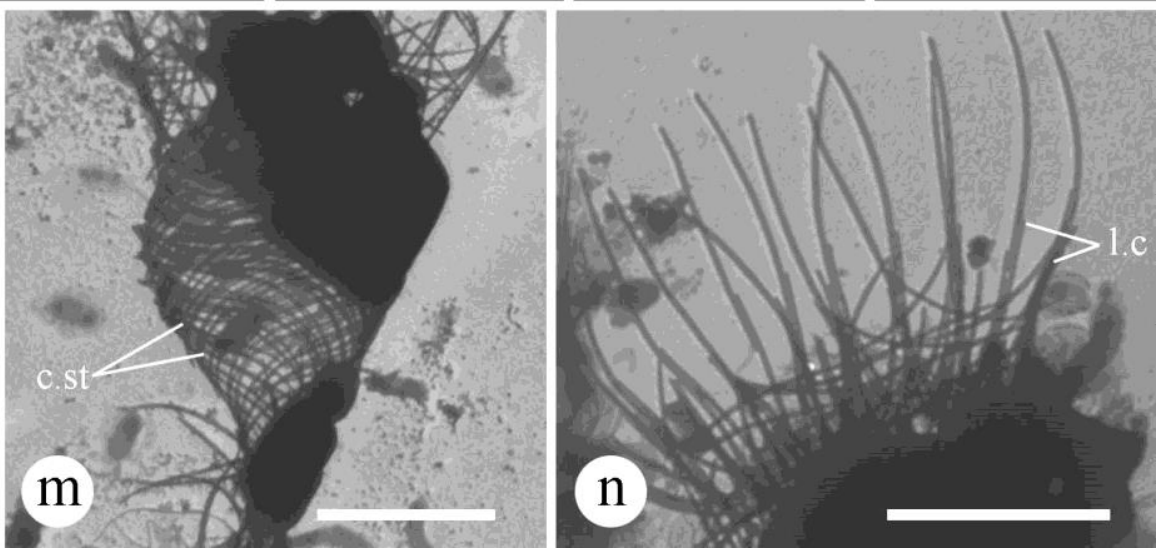


bioRxiv preprint doi: https://doi.org/10.1101/2020.08.10.243865; this version posted August 10,2020 . The copyright holder for this preprint (which was not certified by peer review) is the author/funder, who has granted bioRxiv a license to display the preprint in perpetuity. It is made available under aCC-BY-ND 4.0 International license.

\section{Figure 2}
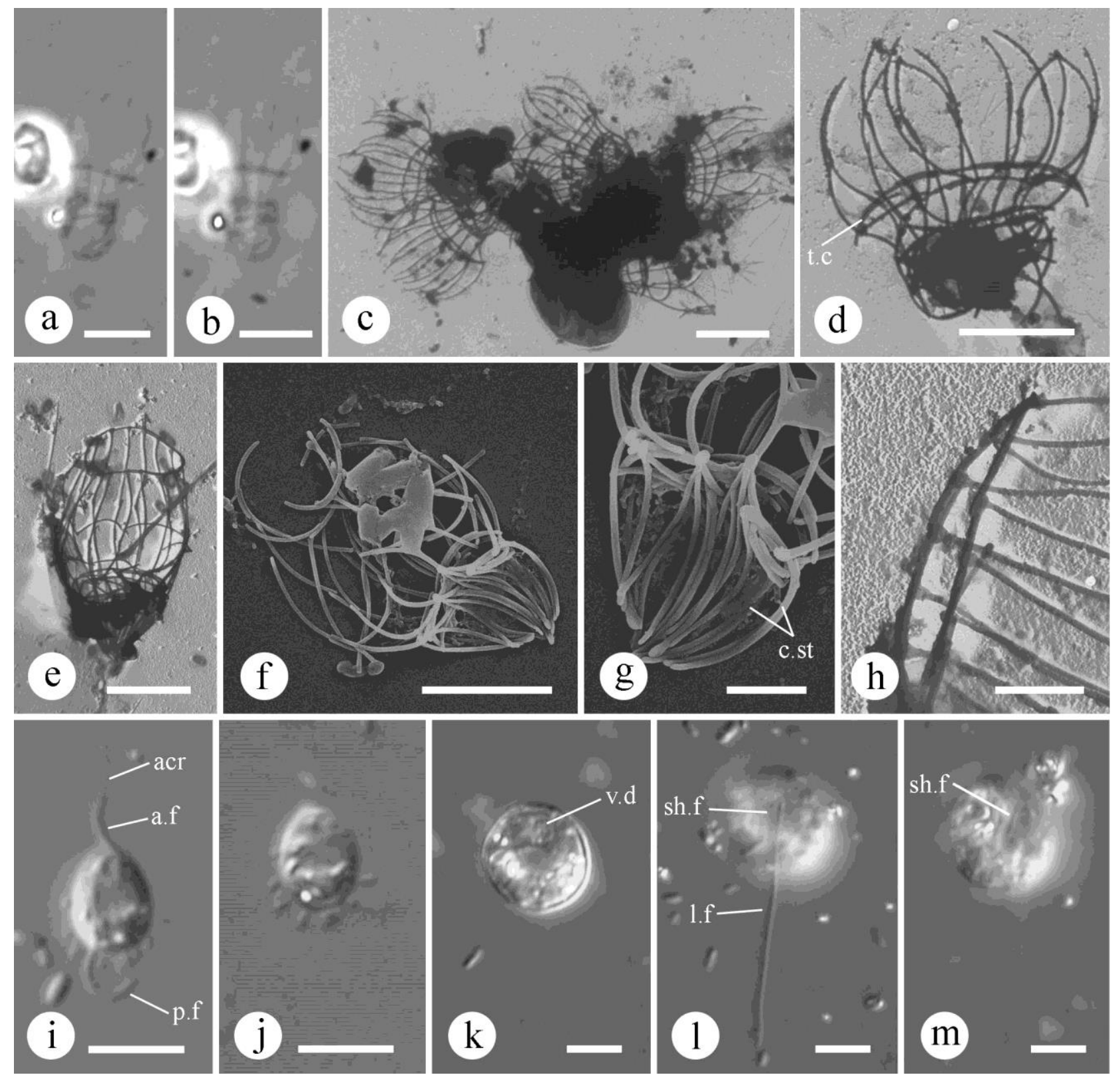

1477 
bioRxiv preprint doi: https://doi.org/10.1101/2020.08.10.243865; this version posted August 10, 2020. The copyright holder for this preprint (which was not certified by peer review) is the author/funder, who has granted bioRxiv a license to display the preprint in perpetuity. It is made available under aCC-BY-ND 4.0 International license.

\section{Figure 3}
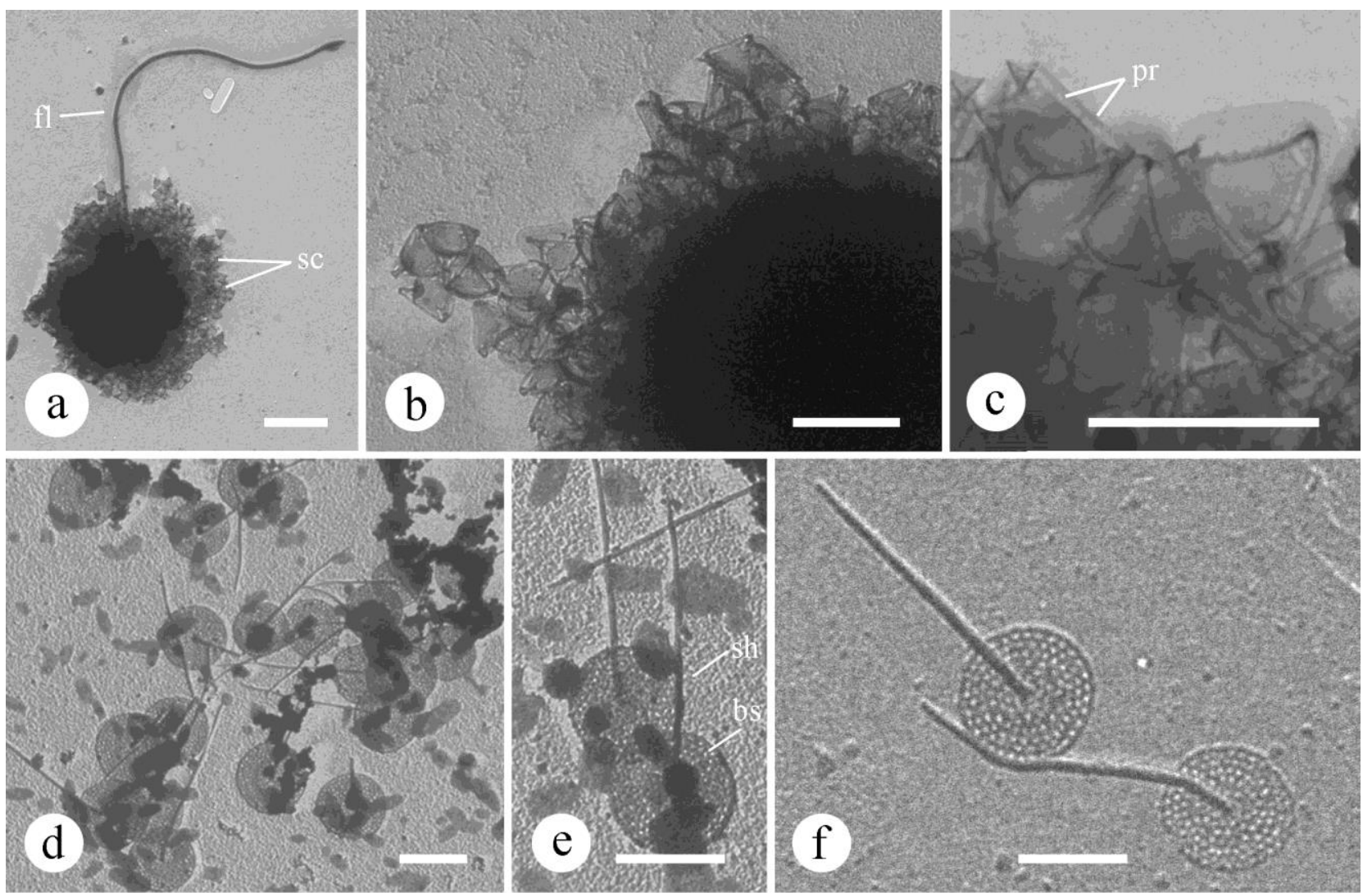

1479
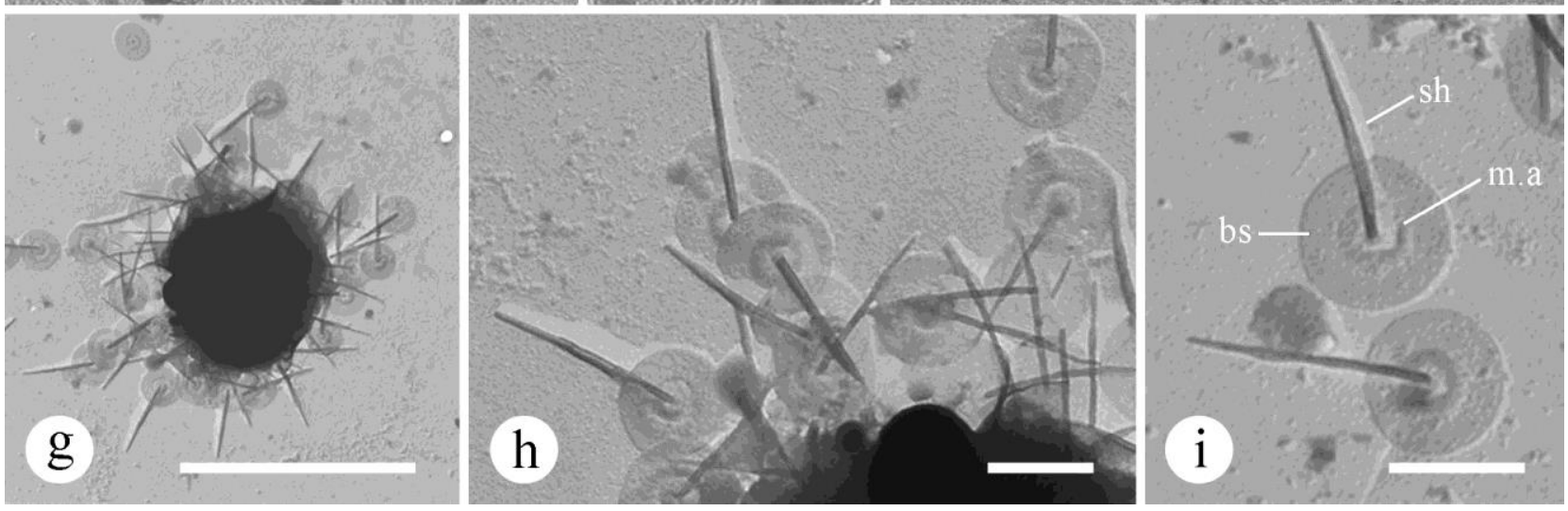
bioRxiv preprint doi: https://doi.org/10.1101/2020 08.10.243865; this version posted August 10,2020 . The copyright holder for this preprint (which was not certified by peer review) is the author/funder, who has granted bioRxiv a license to display the preprint in perpetuity. It is made available under aCC-BY-ND 4.0 International license.

1481 Figure 4
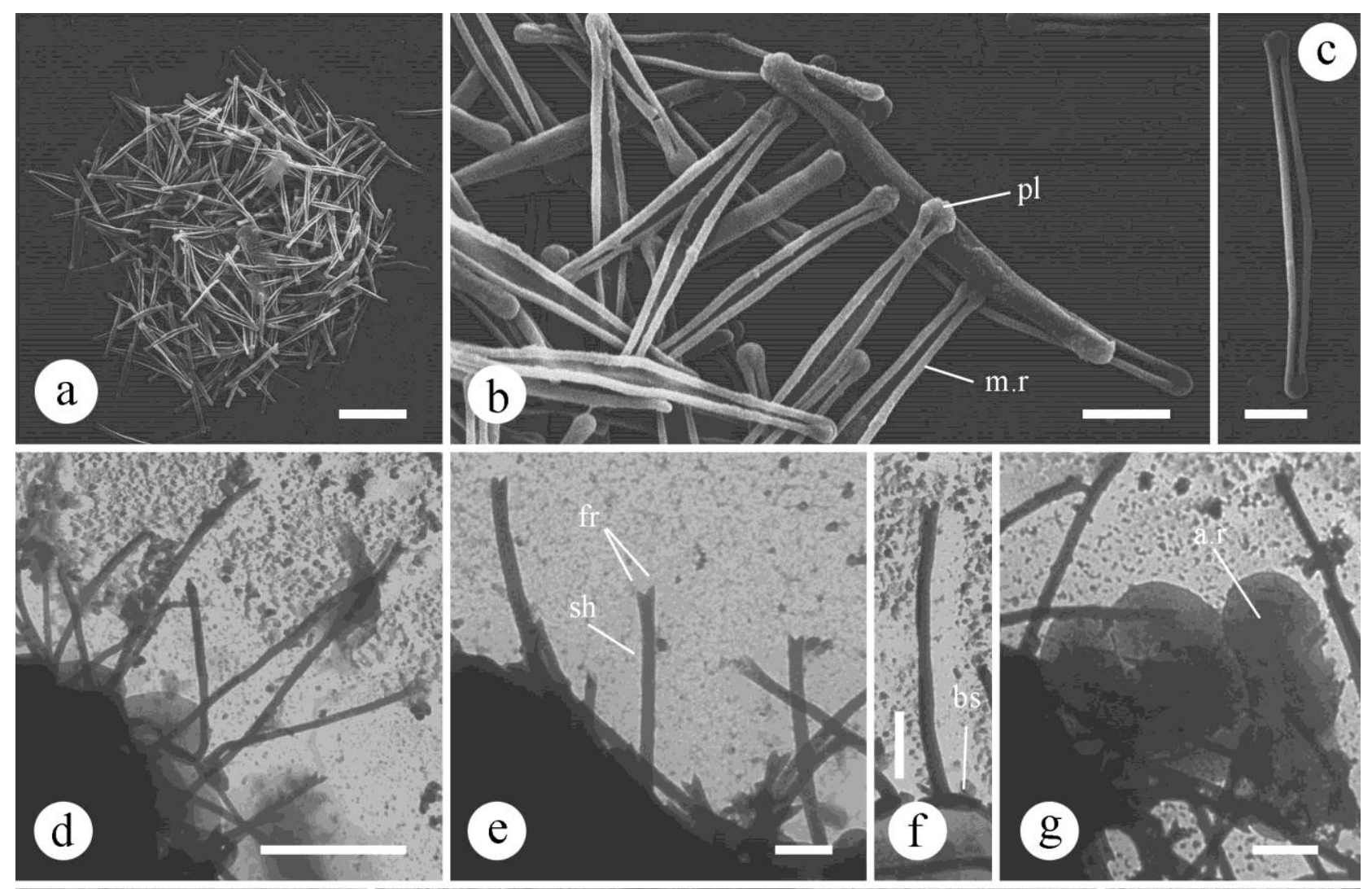

1482
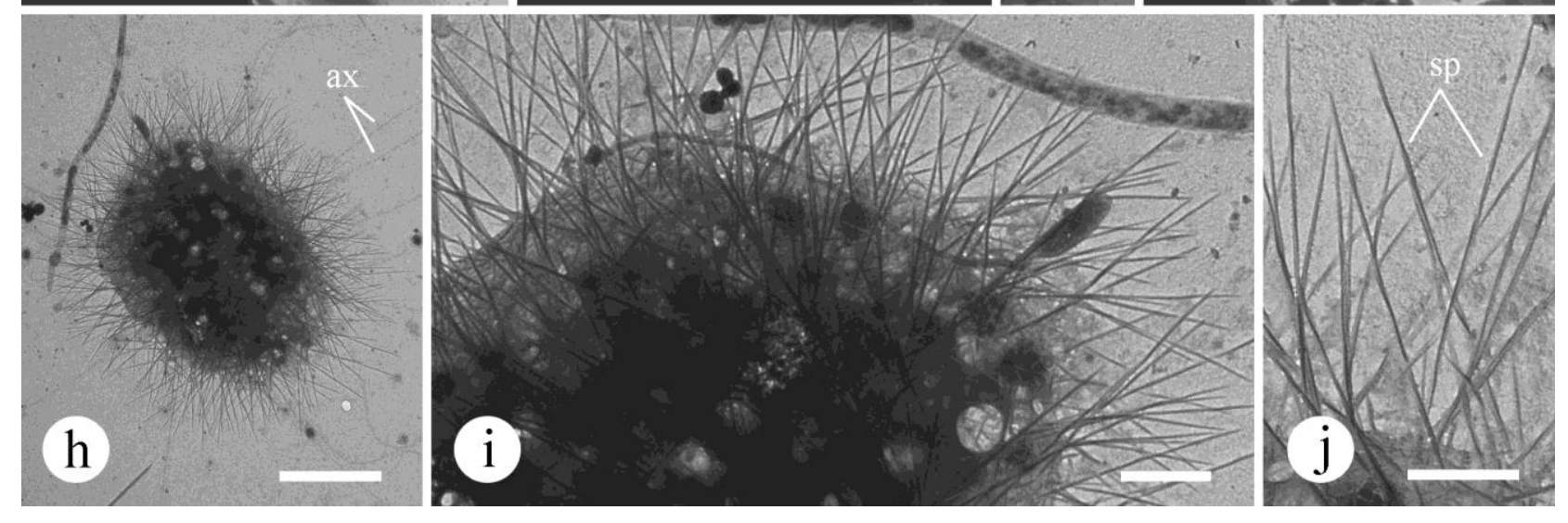

1483 
bioRxiv preprint doi: https://doi.org/10.1101/2020.08.10.243865; this version posted August 10, 2020. The copyright holder for this preprint (which was not certified by peer review) is the author/funder, who has granted bioRxiv a license to display the preprint in perpetuity. It is made available under aCC-BY-ND 4.0 International license.

\section{Figure 5}
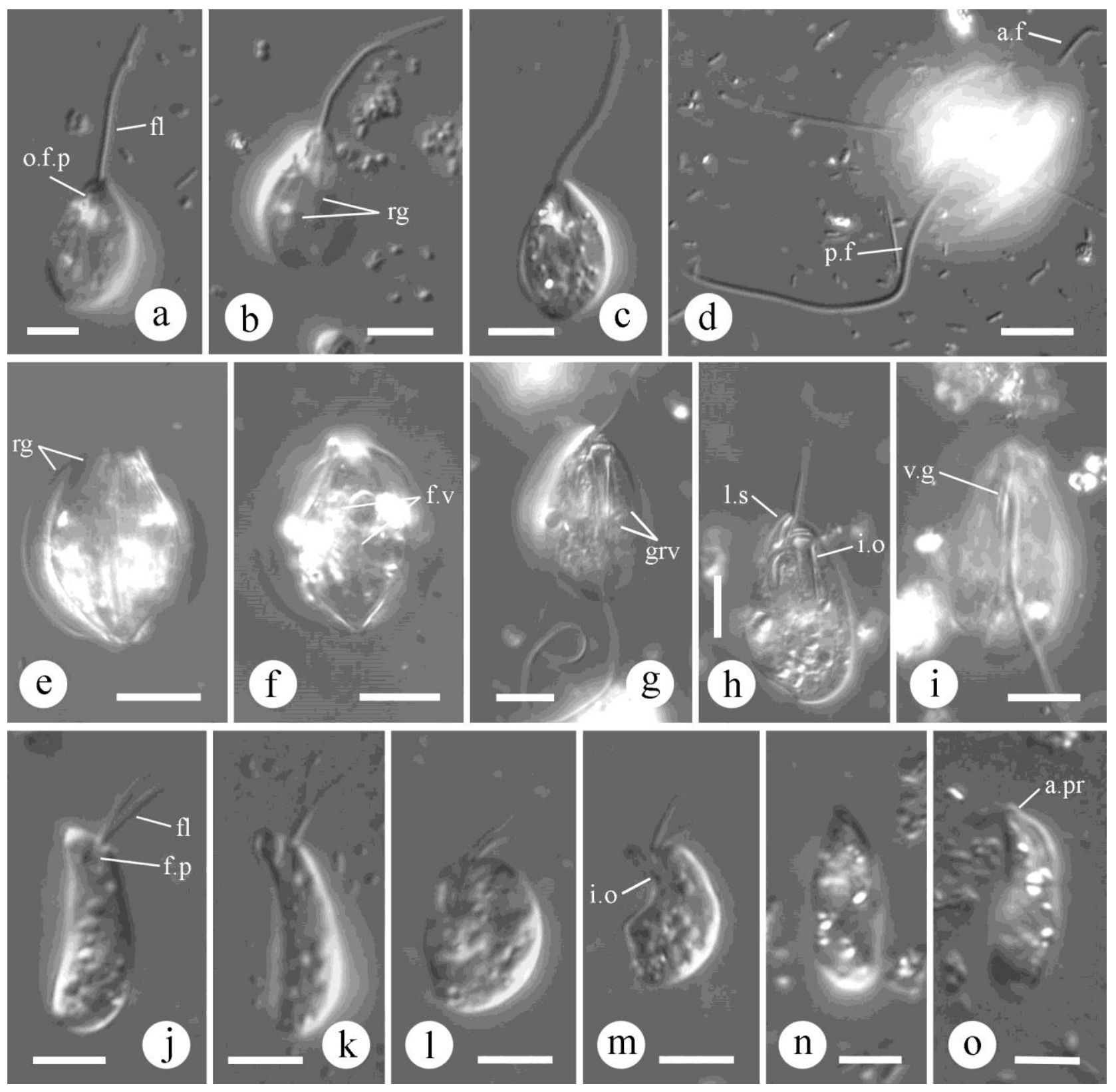
bioRxiv preprint doi: https://doi.org/10.1101/2020.08.10.243865; this version posted August 10, 2020. The copyright holder for this preprint (which was not certified by peer review) is the author/funder, who has granted bioRxiv a license to display the preprint in perpetuity. It is made available under aCC-BY-ND 4.0 International license.

\section{Figure 6}

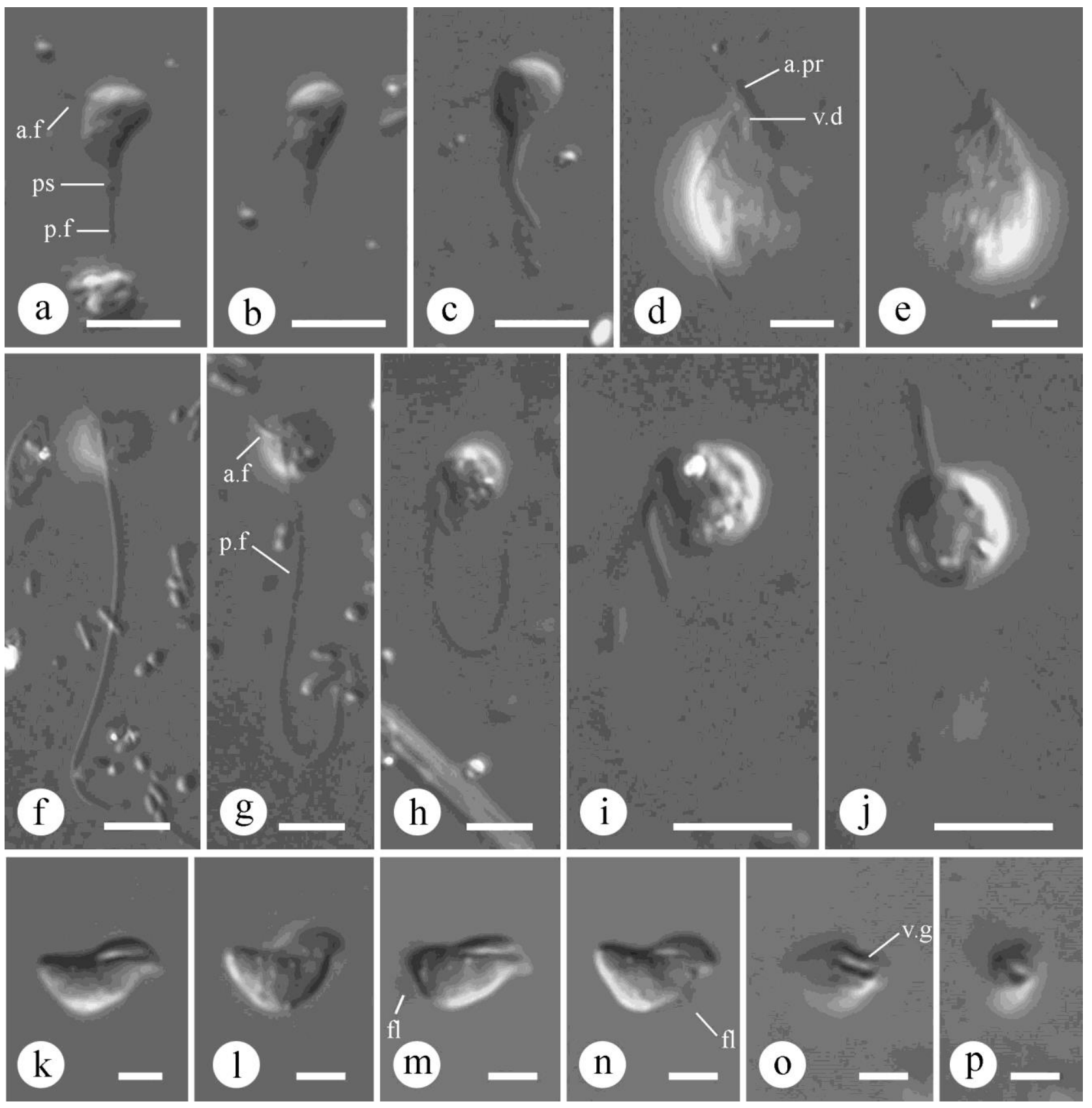


bioRxiv preprint doi: https://doi.org/10.1101/2020.08.10.243865; this version posted August 10, 2020. The copyright holder for this preprint (which was not certified by peer review) is the author/funder, who has granted bioRxiv a license to display the preprint in perpetuity. It is made available under aCC-BY-ND 4.0 International license.

$1490 \quad$ Figure 7

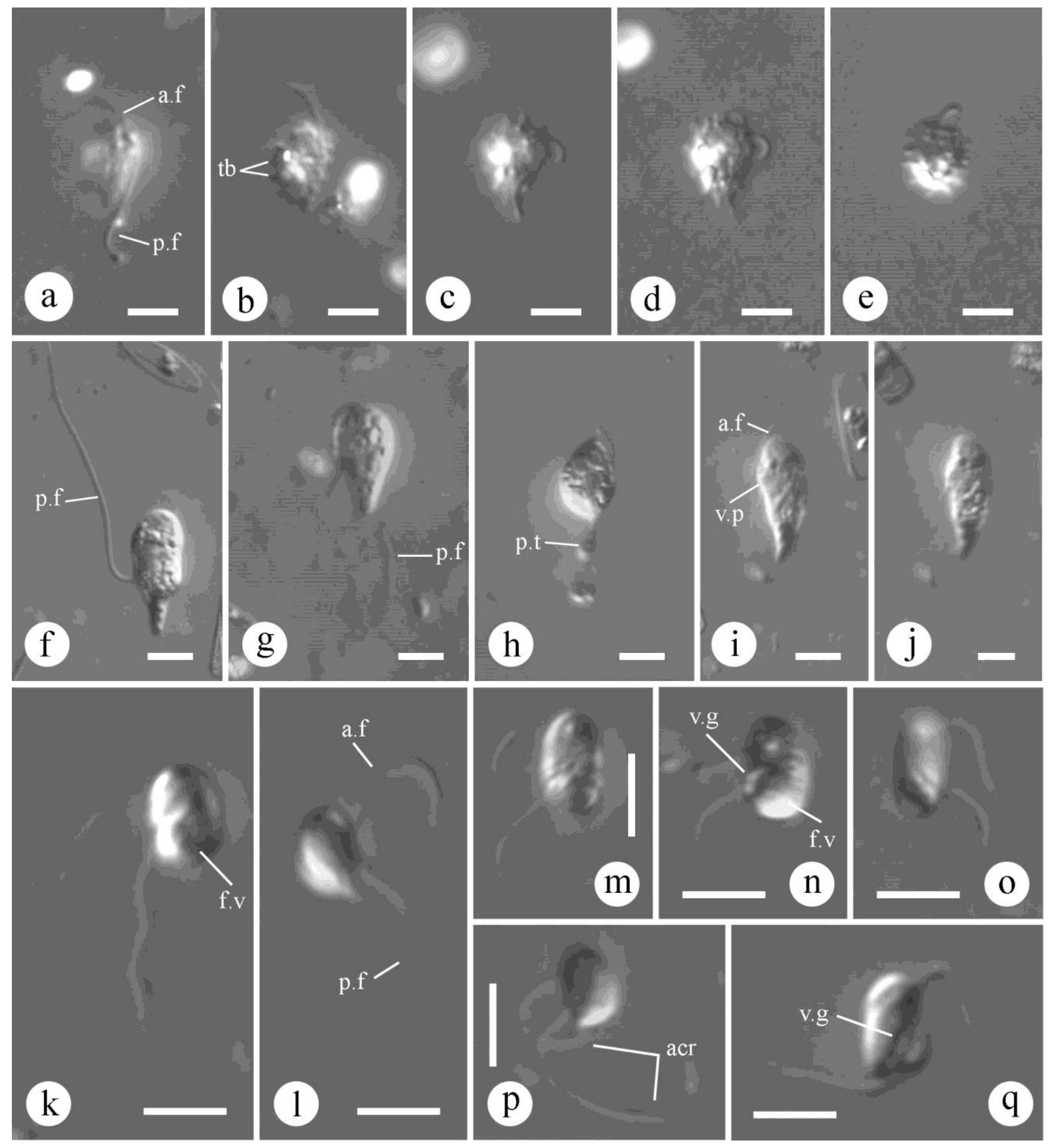


bioRxiv preprint doi: https://doi.org/10.1101/2020.08.10.243865; this version posted August 10, 2020. The copyright holder for this preprint (which was not certified by peer review) is the author/funder, who has granted bioRxiv a license to display the preprint in perpetuity. It is made available under aCC-BY-ND 4.0 International license.

1493 Figure 8

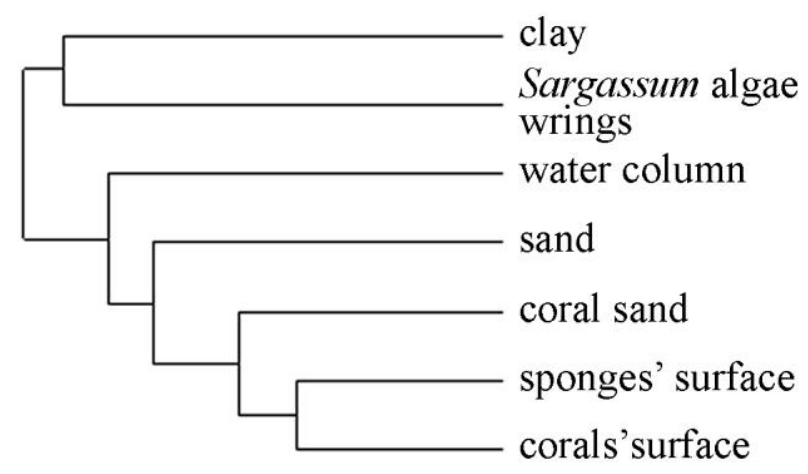

1494

$20 \quad 30 \quad 40 \quad 50 \quad 60 \quad 70 \quad 80 \quad 90100$

1495

1496 
bioRxiv preprint doi: https://doi.org/10.1101/2020.08.10.243865; this version posted August 10, 2020. The copyright holder for this preprint (which was not certified by peer review) is the author/funder, who has granted bioRxiv a license to display the preprint in perpetuity. It is made available under aCC-BY-ND 4.0 International license.

1497 Figure 9

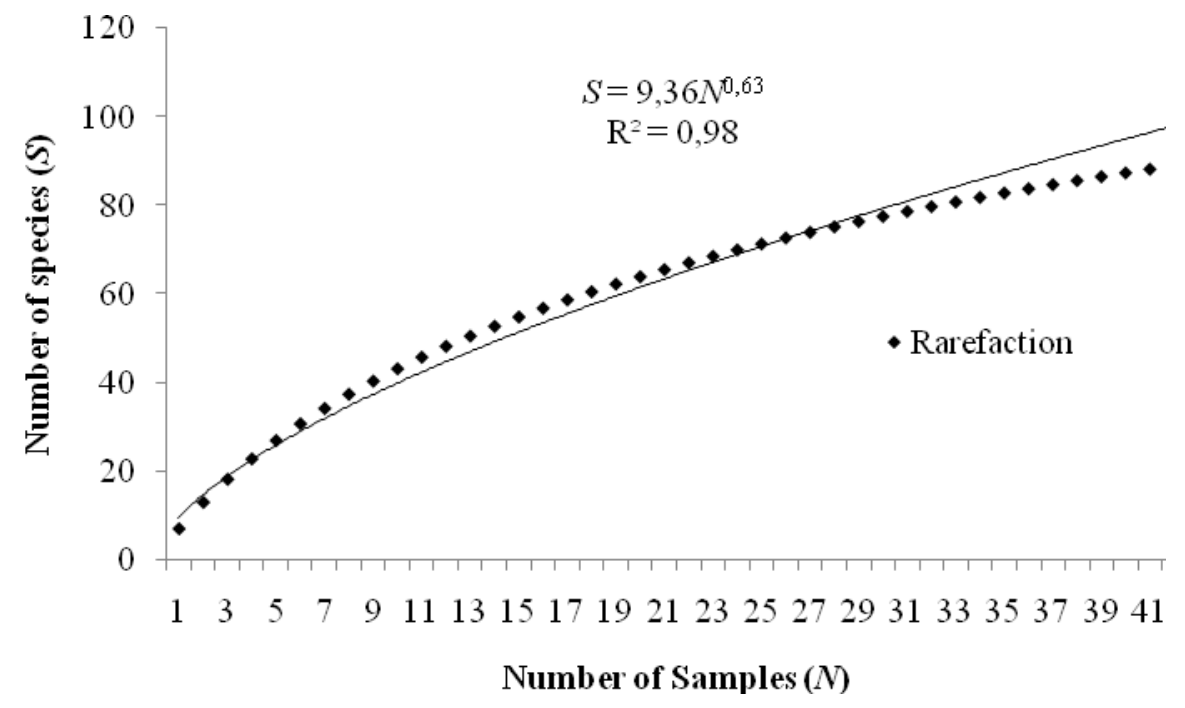

1499 